\title{
Lithium niobate: from single crystals to nanocrystals
}

László Kovács*, Laura Kocsor, Gabriella Dravecz, László Péter, Krisztián Lengyel, and Gábor Corradi

Wigner Research Centre for Physics, Konkoly-Thege M. út 29-33, 1121 Budapest, Hungary

* Corresponding author: kovacs.laszlo@wigner.hu

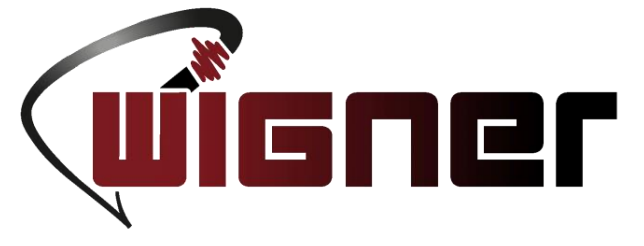


Abstract: $\mathrm{LiNbO}_{3}$ single crystals were first grown more than 50 years ago. Since that time thousands of papers have been published dealing with their outstanding ferroelectric, acoustic, nonlinear optical, holographic etc. properties and demonstrating their countless realized or potential applications. It was about 25 years ago, when the first stoichiometric $\mathrm{LiNbO}_{3}$ crystals gave a new impulse to the neverending investigations. Different applications require different undoped or doped systems of bulk, thin film, or nanocrystal forms. In the present talk I'll show two examples, (i) incorporation of dopants into stoichiometric crystals, and (ii) properties of $\mathrm{LiNbO}_{3}$ nanocrystals prepared by high-energy ball-milling.

Dopants are generally used to tailor the crystal properties for a given application. To understand the effect of dopants the substitution site in the crystal have to be known. Our IR absorption studies unambiguously showed that for the di-, tri-, and tetravalent cations a threshold concentration exists above which the dopants partially substitute at $\mathrm{Nb}$ sites, while below it they can be found on Li sites.

Nano-crystalline $\mathrm{LiNbO}_{3}$ was prepared from single crystals by the high-energy ballmilling technique. During milling the material suffered partial reduction that lead to the formation of bipolarons and polarons yielding gray color together with $\mathrm{Li}_{2} \mathrm{O}$ segregation on the open surfaces. Upon high temperature oxidation a $\mathrm{LiNb}_{3} \mathrm{O}_{8}$ shell was formed. The particle size of the nano-crystals were determined by dynamic light scattering (DLS) and scanning electron microscopic (SEM) methods.

Keywords: lithium niobate; single crystal; nanocrystal; 


\section{OUTLINE}

\section{i) Dopant sites in stoichiometric $\mathrm{LiNbO}_{3}$ single crystals}

- Stoichiometric vs. congruent $\mathrm{LiNbO}_{3}(\mathrm{SLN} \leftrightarrow \mathrm{CLN})$

- Hydroxyl ions in SLN

- Optical damage resistant (ODR) ions

- Rare-earth (RE) ions

- Transition metal (TM) ions $\left(\mathrm{Fe}^{3+}, \mathrm{Cr}^{3+}, \mathrm{Ti}^{4+}\right)$

ii) Mechanochemical reactions of $\mathrm{LiNbO}_{3}$ induced by high-energy ball-milling

- Lithium niobate nanocrystals

- High-energy ball-milling (dry and wet grinding)

- Particle and grain size reduction

- Phase transformation and chemical reaction

- Structure characterization (X-ray, Raman, reflection spectroscopy, coulometric titration, electron microscopy) 


\section{i) Stoichiometric vs. congruent $\mathrm{LiNbO}_{3}$}

\section{Phase diagram, crystal growth}

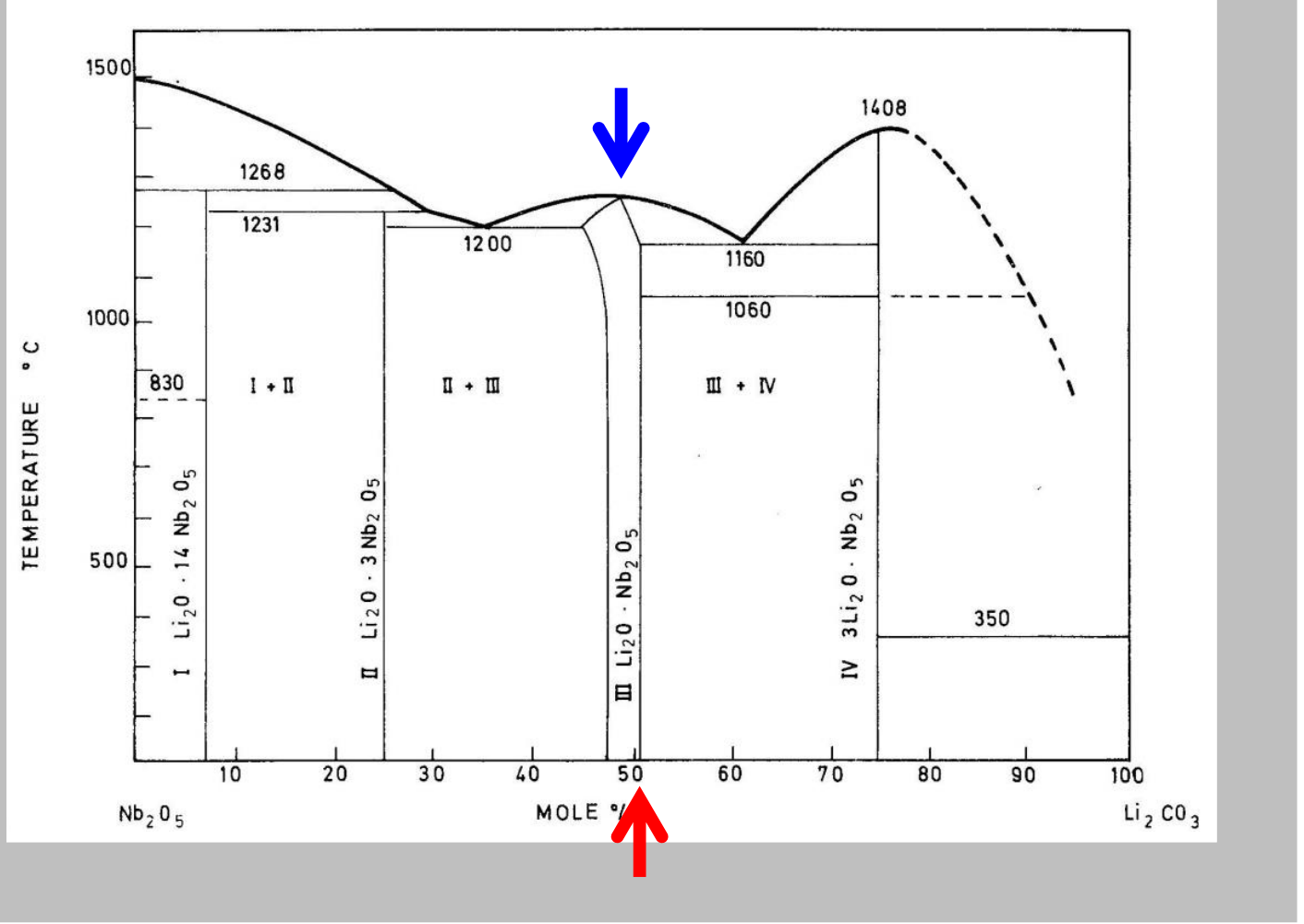

$\mathrm{LiNbO}_{3}$ melts congruently grown by the Czochralski method

$48.4 \mathrm{~mol} \% \mathrm{Li}_{2} \mathrm{O}$

$51.6 \mathrm{~mol} \% \mathrm{Nb}_{2} \mathrm{O}_{5}$

$\mathrm{Li} / \mathrm{Nb} \approx 0.94$

$\mathrm{Li}_{1-5 z} \mathrm{Nb}_{1+\mathrm{z}} \mathrm{O}_{3}(\mathrm{z} \approx 0.01)$

Stoichiometric crystals grown by the HTTSSG method from $\mathrm{K}_{2} \mathrm{O}$ flux

$\mathrm{K} / \mathrm{Nb}=0.31, \mathrm{Li} / \mathrm{Nb}=1$ in the flux $\mathrm{K} \approx 0, \mathrm{Li} / \mathrm{Nb} \approx 1$ in the crystal $\mathrm{LiNbO}_{3}(\mathrm{z} \approx 0)$ 


\section{i) Stoichiometric vs. congruent $\mathrm{LiNbO}_{3}$}

$\mathrm{OH}^{-}$absorption band

$\mathrm{OH}^{-}$ions are probes of the defect structure in $\mathrm{LiNbO}_{3}$

Congruent $(\mathrm{Li} / \mathrm{Nb} \approx 0.94)$

$\mathrm{Li}_{1-5 \mathrm{z}} \mathrm{Nb}_{1+\mathrm{z}} \mathrm{O}_{3}(\mathrm{z} \approx 0.01)$

$v_{\max } \approx 3484 \mathrm{~cm}^{-1}$

Stoichiometric $(\mathrm{Li} / \mathrm{Nb} \approx 1)$

$\mathrm{LiNbO}_{3}(\mathrm{z} \approx 0)$

$v_{\max }=3466 \mathrm{~cm}^{-1}$

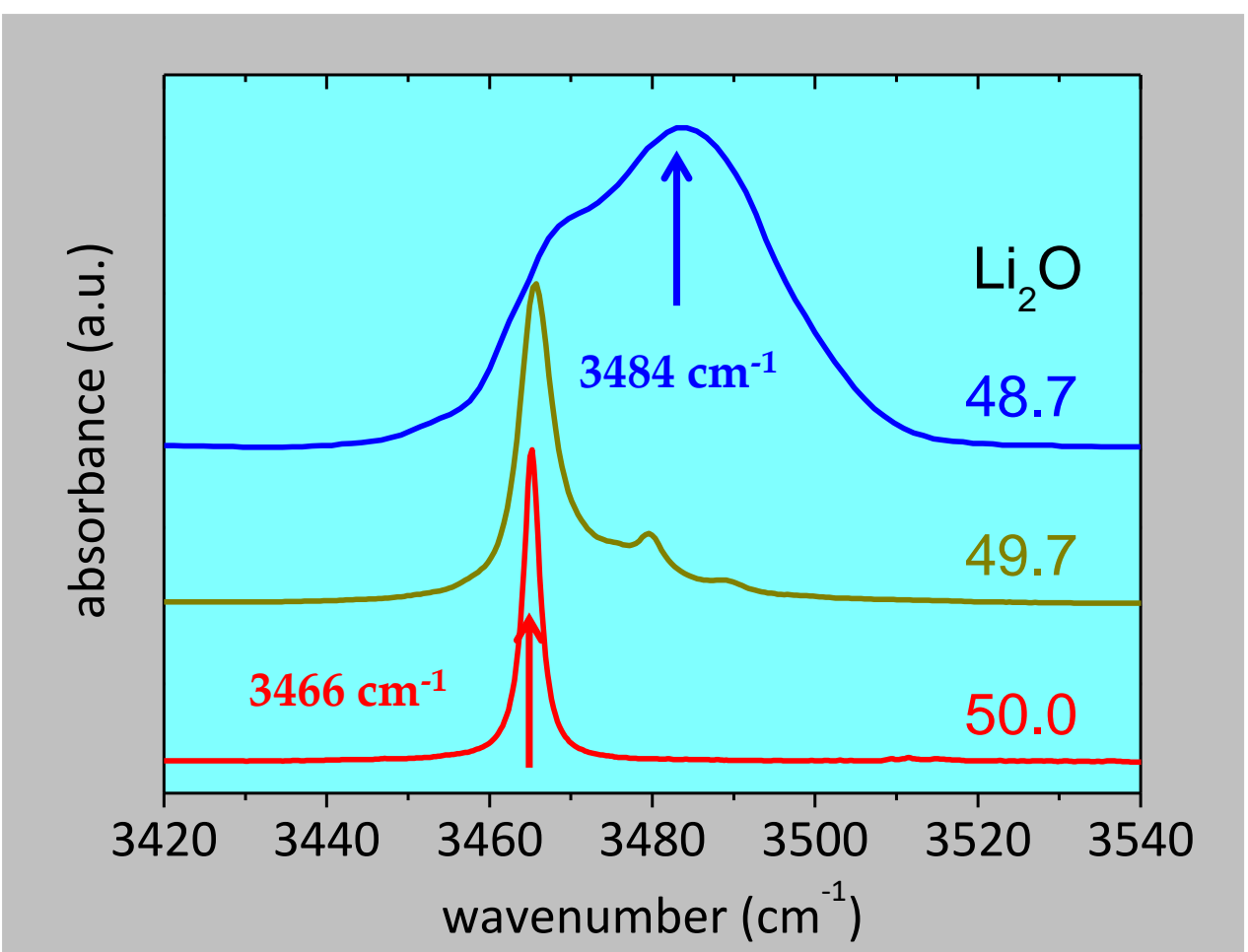

Stretching vibration of $\mathrm{OH}^{-}$ions in $\mathrm{LiNbO}_{3}$ 


\section{i) Dopant ions in $\mathrm{LiNbO}_{3}$}

- Transition metal (TM) ions: $\mathrm{Fe}^{2+/ 3+}, \mathrm{Mn}^{2+}, \mathrm{Cu}^{+/ 2+}, \mathrm{Ni}^{2+}, \mathrm{Cr}^{3+}, \mathrm{Ti}^{4+}$, etc.

- Increase the photorefractive sensitivity utilized in holographic recording

- Surface layer diffused $\mathrm{Ti}^{4+}$ is used in optical waveguides

- Optical damage resistant (ODR) ions: $\mathrm{Mg}^{2+}, \mathrm{Zn}^{2+}, \mathrm{Sc}^{3+}, \mathrm{In}^{3+}, \mathrm{Hf}^{4+}, \mathrm{Zr}^{4+}, \mathrm{Sn}^{4+}$

- ODR ions above a threshold concentration suppress the photorefractive damage

- The threshold concentration depends on the valence state of the dopant and the composition of LN (much lower for stoichiometric LN).

- Rare earth ions: $\mathrm{Pr}^{3+}, \mathrm{Nd}^{3+}, \mathrm{Dy}^{3+}, \mathrm{Er}^{3+}, \mathrm{Yb}^{3+}, \ldots$

- $\quad$ Laser active dopants, $4 \mathrm{f}-4 \mathrm{f}$ transitions

- Quantum Information Processing (QIP), Quantum Optics 


\section{i) Threshold concentration of ODR dopants}

Below threshold $\mathrm{M}^{\mathrm{n}+} \rightarrow \mathrm{Li}^{+}$for $\mathrm{n}=2,3,4$ reducing the number of $\mathrm{Nb}_{\mathrm{Li}}$

Above threshold $\mathrm{M}^{\mathrm{n}+} \rightarrow \mathrm{Li}^{+}$and $\mathrm{Nb}^{5+}$ no $\mathrm{Nb}_{\mathrm{Li}}$ ions are left in the crystal

Congruent $\mathrm{LiNbO}_{3}\left(\mathrm{Li}_{1-5 \mathrm{z}} \mathrm{Nb}_{1+\mathrm{z}} \mathrm{O}_{3}(\mathrm{z} \approx 0.01), \mathrm{Nb}_{\mathrm{Li}} \approx 0.01\right)$

Stoichiometric $\mathrm{LiNbO}_{3}\left(\mathrm{Li}_{1-5 \mathrm{z}} \mathrm{Nb}_{1+\mathrm{z}} \mathrm{O}_{3}(\mathrm{z} \approx 0), \mathrm{Nb}_{\mathrm{Li}} \approx 0\right)$

No excess $\mathrm{Nb}-$ no $\mathrm{Nb}_{\mathrm{Li}} \mathrm{C}_{\mathrm{th}} \approx 0 \mathrm{~mol} \%$

Experimentally - almost fulfilled

- for $\mathrm{Mg}^{2+} \mathrm{C}_{\mathrm{th}} \approx 0.2 \mathrm{~mol} \%$ in $\mathrm{sLN}<<\mathrm{C}_{\mathrm{th}} \approx 5 \mathrm{~mol} \%$ in cLN

- for $\mathrm{Zr}^{4+} \quad \mathrm{C}_{\mathrm{th}} \approx 0.09 \mathrm{~mol} \%$ in sLN $\ll<\mathrm{C}_{\mathrm{th}} \approx 2 \mathrm{~mol} \%$ in cLN

The $\mathrm{OH}^{-}$absorption spectrum is one of the best indicator of the threshold effect 


\section{i) Hydroxyl ions in ODR ion doped SLN}

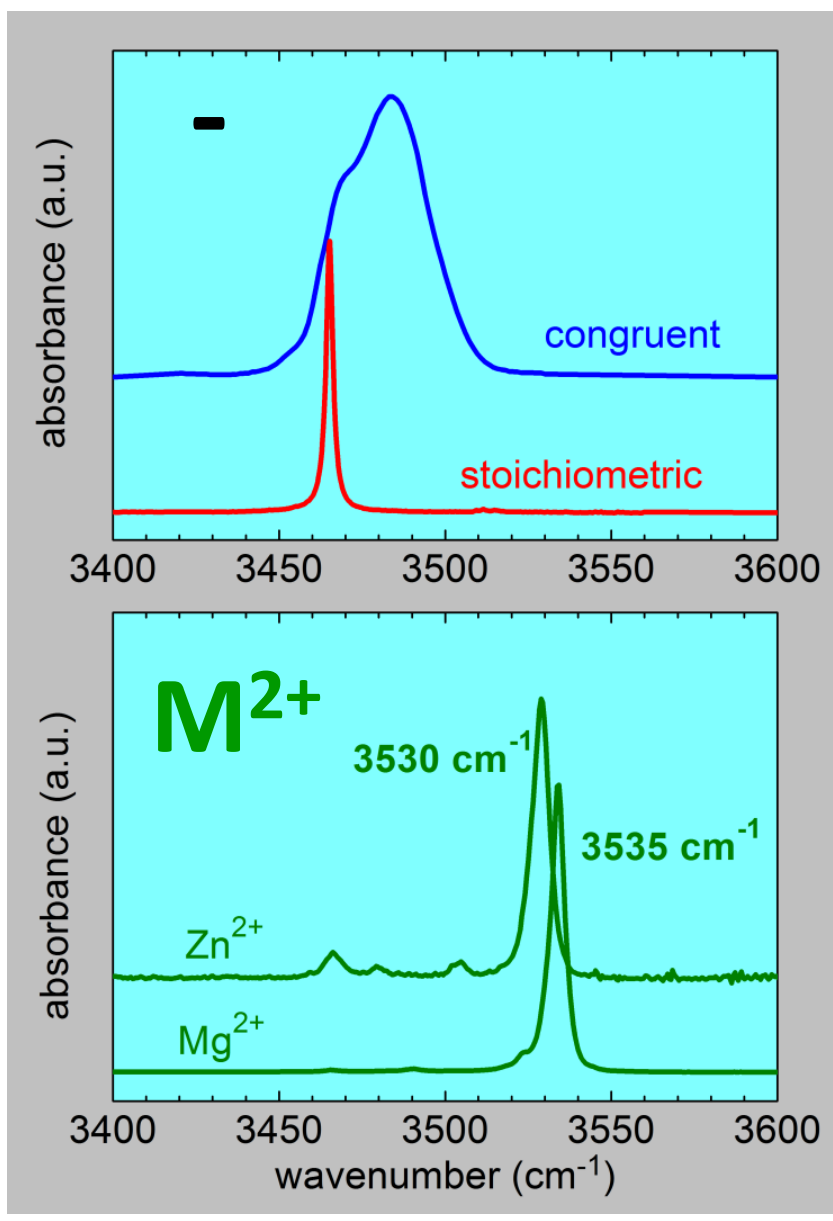

\begin{tabular}{|l|r|r|}
\hline \begin{tabular}{|} 
ODR \\
ion
\end{tabular} & \multicolumn{2}{|c|}{$\begin{array}{r}\text { OH- vibrational } \\
\text { frequency } \\
\text { (cm-1) }\end{array}$} \\
\hline $\mathrm{Mg}^{2+}$ & 3466 & 3535 \\
\hline $\mathrm{Zn}^{2+}$ & 3466 & 3530 \\
\hline $\mathrm{In}^{3+}$ & 3466 & 3504 \\
\hline $\mathrm{Sc}^{3+}$ & 3466 & 3505 \\
\hline $\mathrm{Hf}^{4+}$ & 3466 & 3476 \\
\hline $\mathrm{Zr}^{4+}$ & 3466 & 3475 \\
\hline $\mathrm{Sn}^{4+}$ & 3466 & 3474 \\
\hline
\end{tabular}

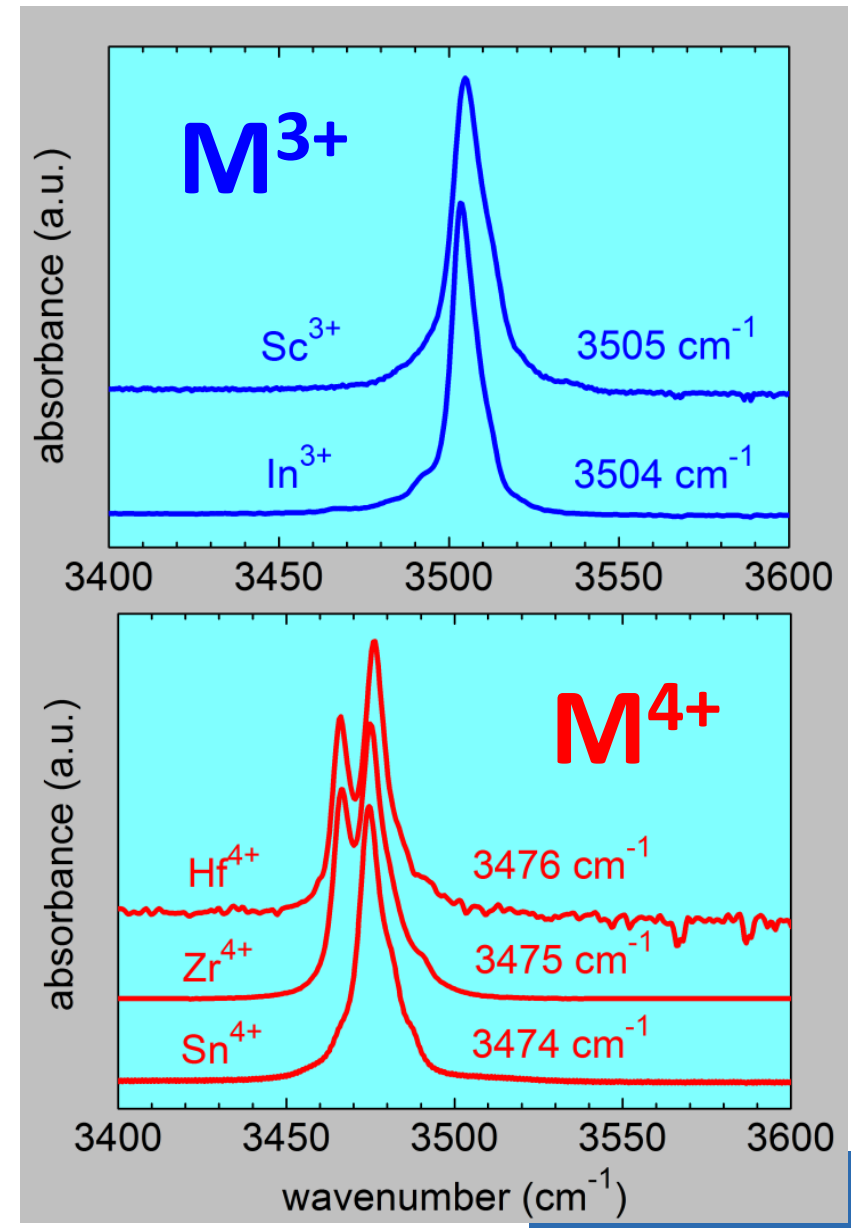

L. Kovács, Zs. Szaller, K. Lengyel, G. Corradi: Hydroxyl ions in stoichiometric $\mathrm{LiNbO}_{3}$ crystals doped with optical damage resistant ions, Optical Materials, 37, 55-58, 2014.

Crystals 2020 


\section{i) Hydroxyl ions in ODR ion doped SLN}
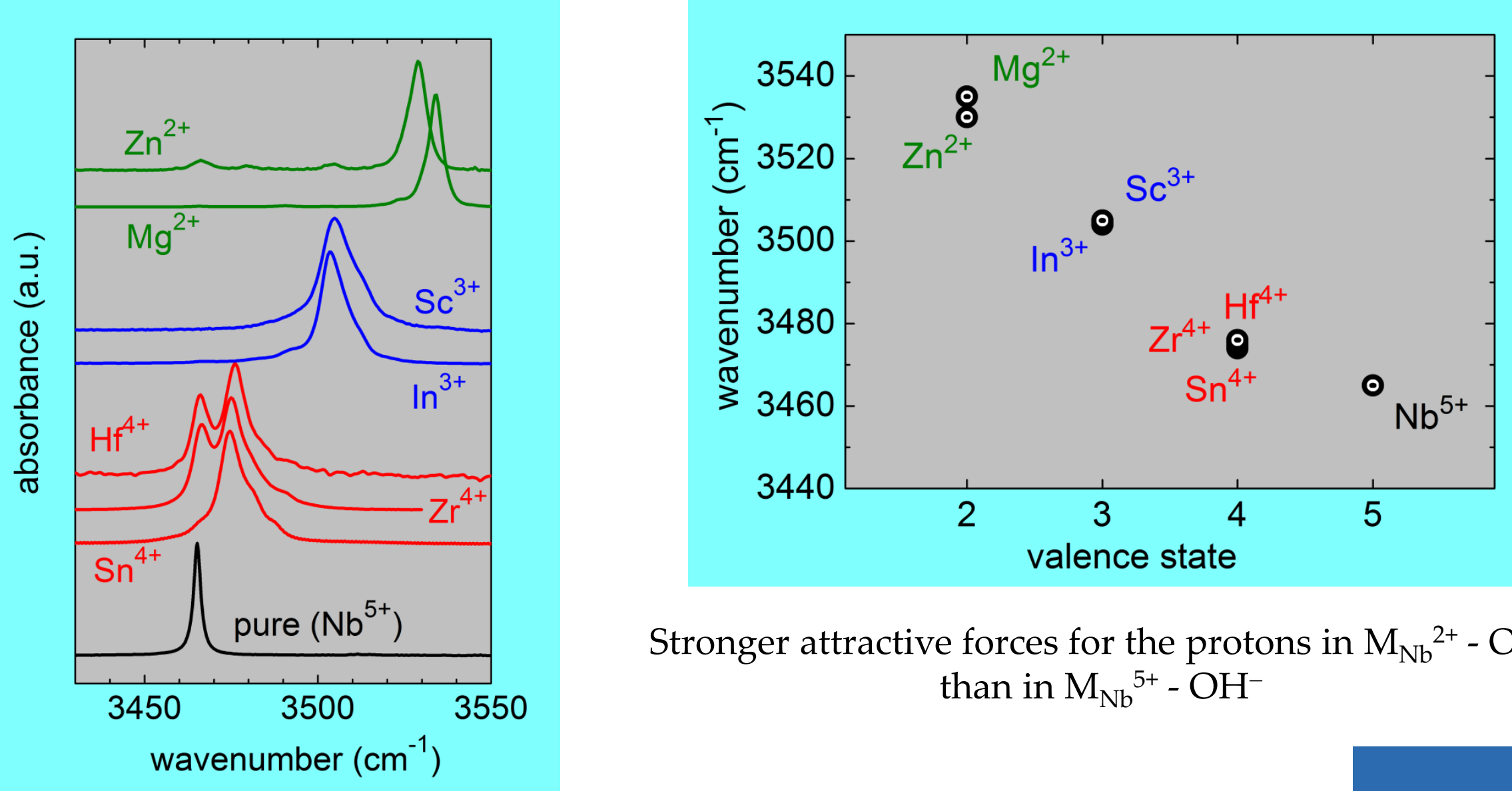

Stronger attractive forces for the protons in $\mathrm{M}_{\mathrm{Nb}}{ }^{2+}-\mathrm{OH}^{-}$ than in $\mathrm{M}_{\mathrm{Nb}}{ }^{5+}-\mathrm{OH}^{-}$ 


\section{i) Hydroxyl ions in ODR ion doped SLN}
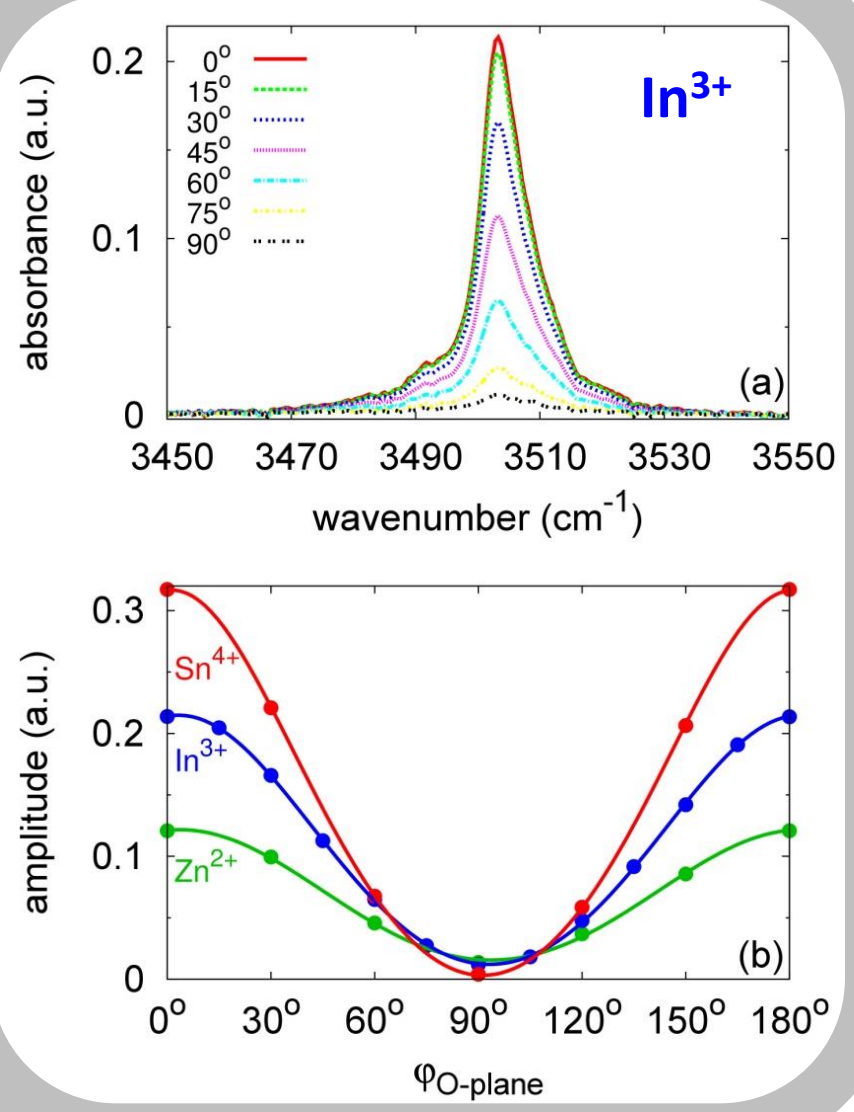

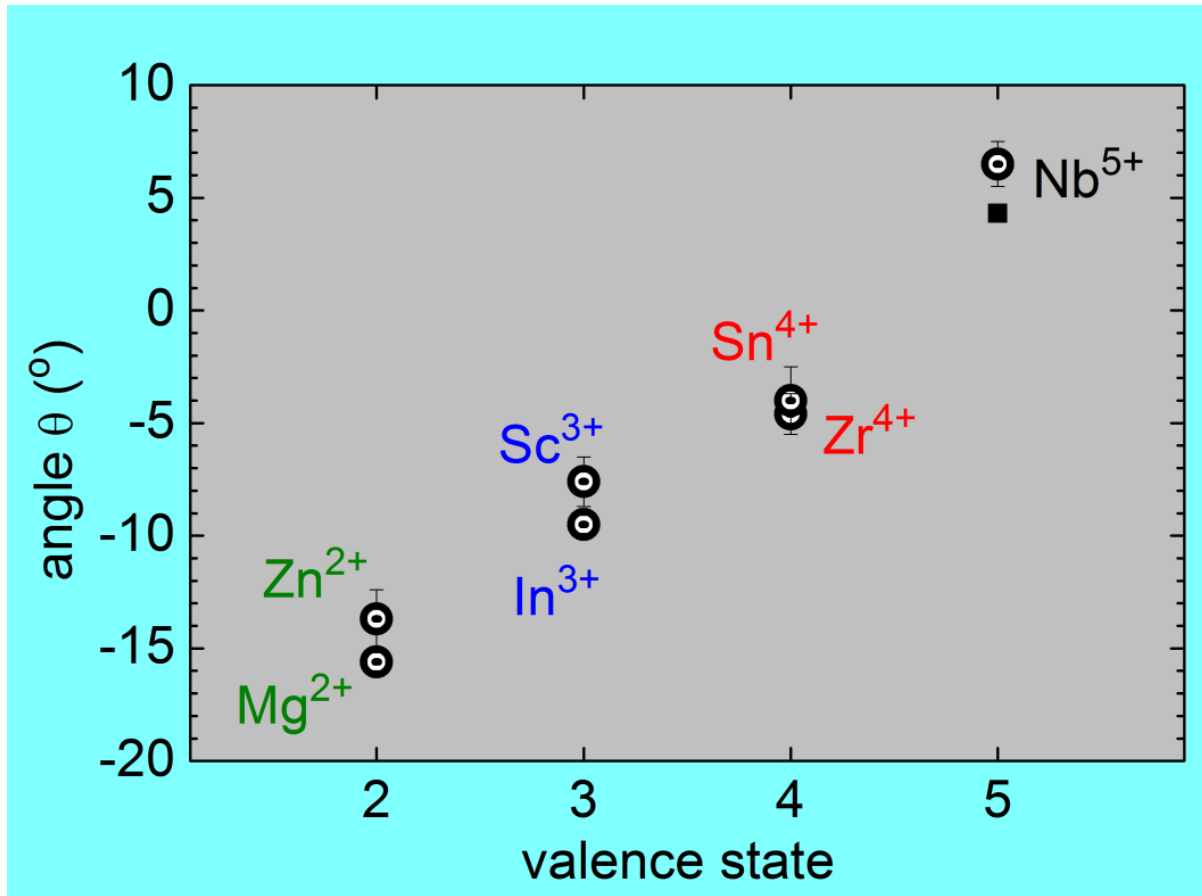

$\theta$ is the angle between the $\mathrm{O}-\mathrm{H}$ bond and the oxygen plane $\perp$ to the $\mathrm{c}$ axis 


\section{i) Hydroxyl ions in ODR ion doped SLN}

- The new $\mathrm{OH}^{-}$band is present if $\mathrm{C}_{\mathrm{M}^{\mathrm{n}+}}$ is above the threshold

- $\mathrm{OH}^{-}$is close to $\mathrm{M}^{\mathrm{n}+}$

- Above threshold $\mathrm{M}^{\mathrm{n}+}$ at least partially occupies $\mathrm{Nb}$ site

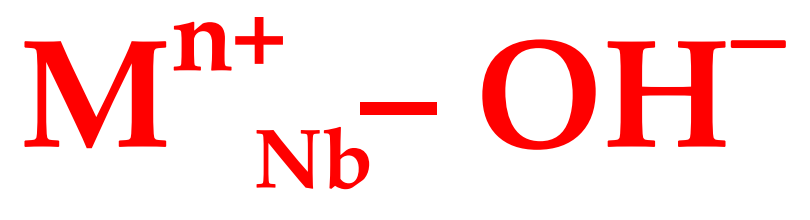

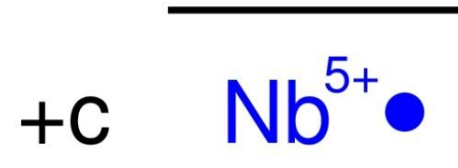

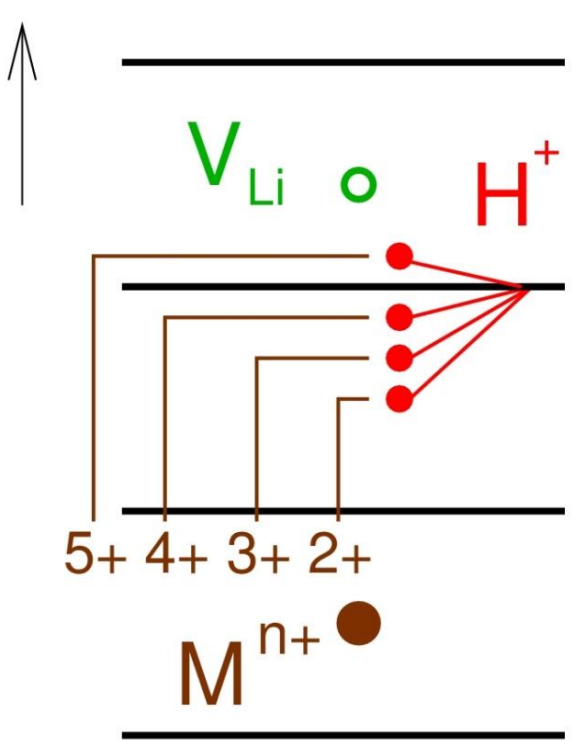


i) Dopants in stoichiometric $\mathrm{LiNbO}_{3}$

The defect model

$$
\mathrm{M}_{\mathrm{Nb}}^{\mathrm{n}+}-\mathrm{OH}^{-}
$$

based on the "threshold effect" is valid for all ODR ions.

It should also work for $\mathrm{M}^{\mathrm{n}+}=\mathrm{RE}^{\mathrm{n}+}$ and $\mathrm{TM}^{\mathrm{n}+}$ ions! 


\section{i) Hydroxyl ions in $\mathrm{RE}^{3+}$-doped SLN}
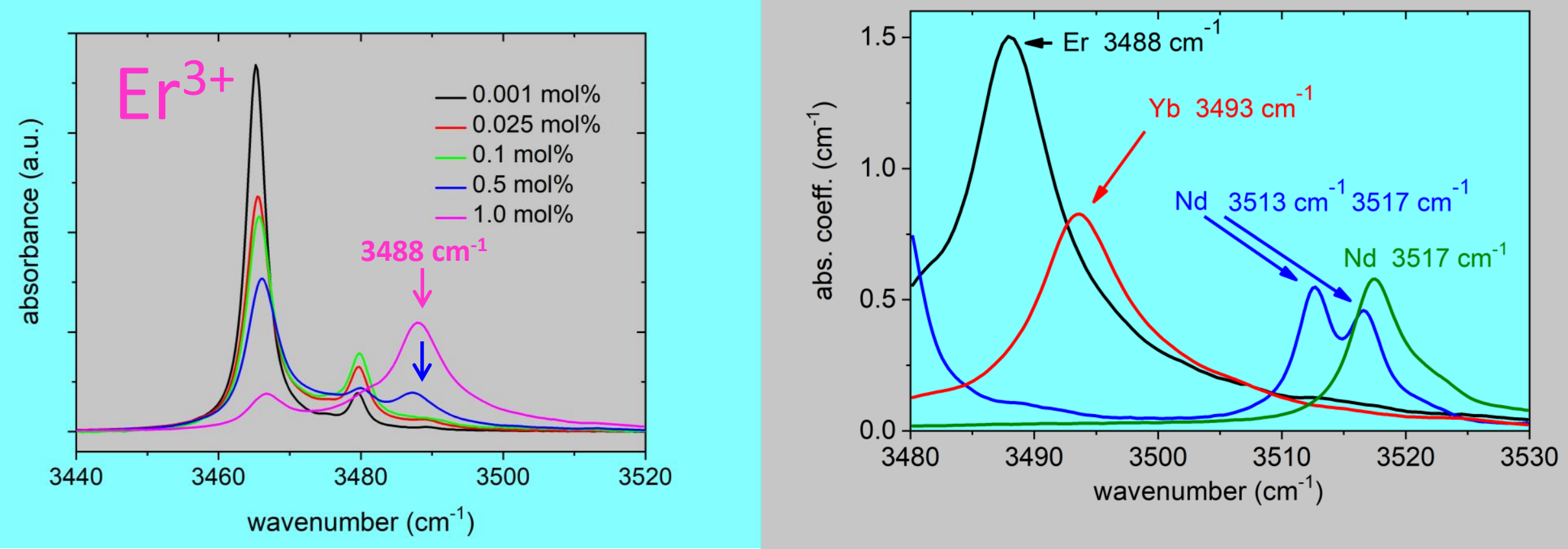

- Above a threshold Er concentration a new $\mathrm{OH}^{-}$band appears at $\approx 3488 \mathrm{~cm}^{-1}$

- $\mathrm{New} \mathrm{OH}^{-}$bands appear for other $\mathrm{RE}^{3+}$ ions as well

L. Kovács, L. Kocsor, Zs. Szaller, I. Hajdara, G. Dravecz, K. Lengyel, G. Corradi: Lattice site of rare-earth ions in stoichiometric lithium niobate probed by $\mathrm{OH}^{-}$vibrational spectroscopy, Crystals, 7, 230/1-9, 2017.

Crystals 2020 


\section{i) $\mathrm{RE}^{3+}$ ions in stoichiometric $\mathrm{LiNbO}_{3}$}
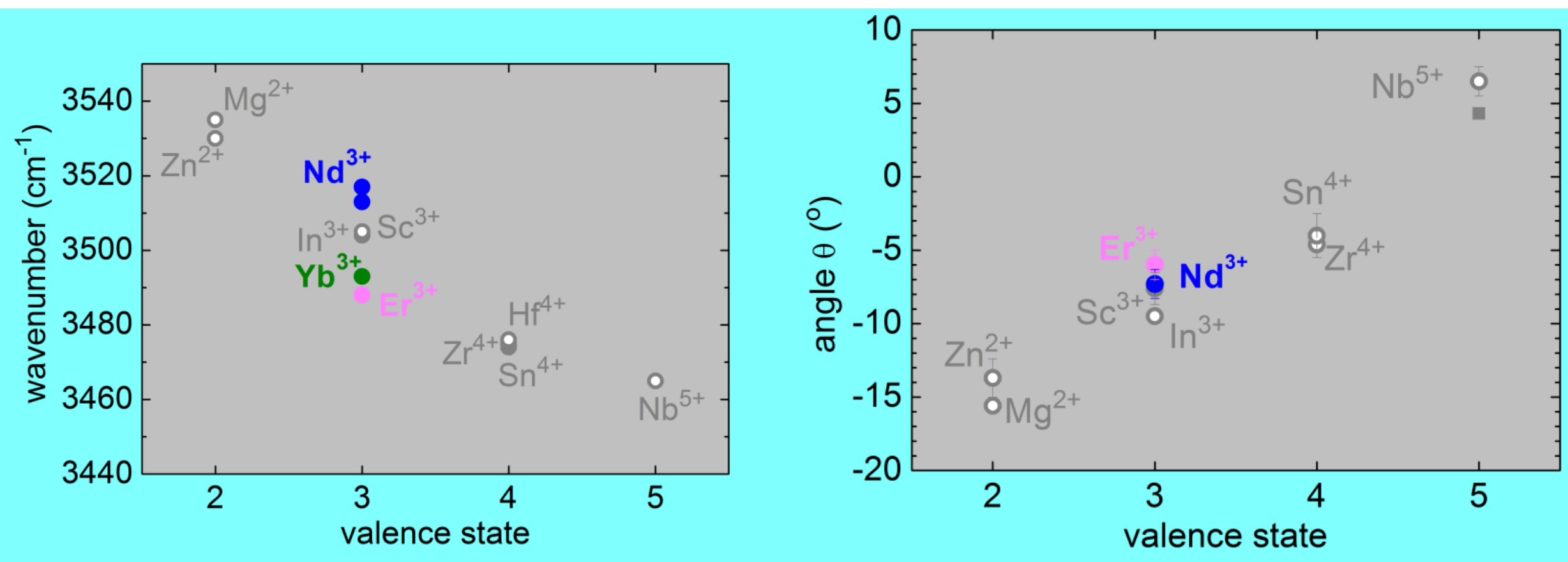

- $\mathrm{RE}^{3+}$ ions fit into the incorporation model of ODR ions 


\section{i) $\mathrm{TM}^{\mathrm{n}+}$ ions in stoichiometric $\mathrm{LiNbO}_{3}$}

$\mathrm{Ti}^{4+}, \mathrm{Fe}^{3+}, \mathrm{Fe}^{3+}+\mathrm{Ti}^{4+}$ and $\mathrm{Cr}^{3+}$ doped SLN crystals were grown by the HTTSSG and Czochralski methods

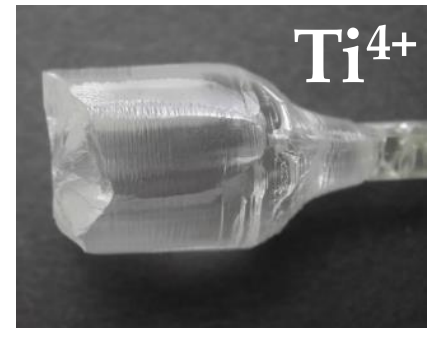

SLN - HTTSSG $0.12 \mathrm{~mol} \% \mathrm{Ti}$

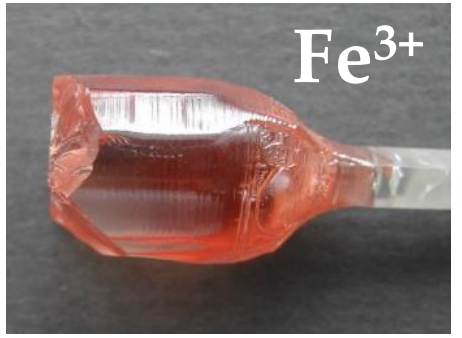

SLN - HTTSSG

$0.12 \mathrm{~mol} \% \mathrm{Fe}$

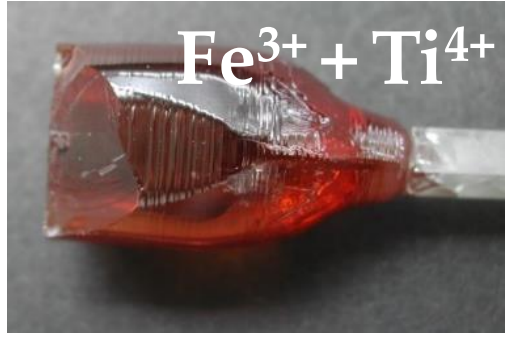

SLN - HTTSSG

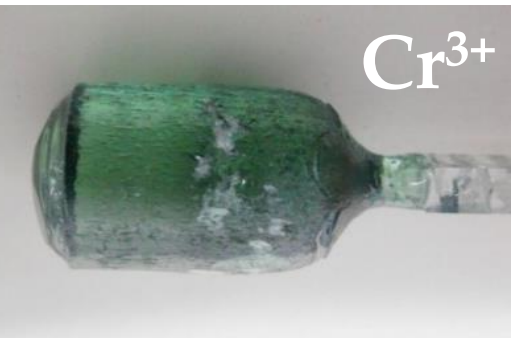

SLN - HTTSSG

$0.5 \mathrm{~mol} \% \mathrm{Cr}$

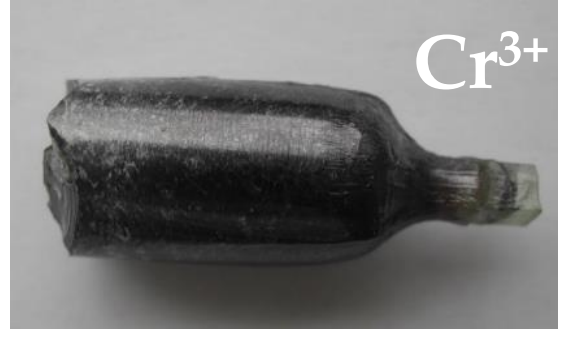

SLN - Czochralski

$0.5 \mathrm{~mol} \% \mathrm{Cr}$ $\mathrm{Li} / \mathrm{Nb}=1.38$

\begin{tabular}{|c|c|c|c|c|c|c|}
\hline \multirow[t]{2}{*}{$\begin{array}{l}\text { Sample } \\
\text { series }\end{array}$} & \multicolumn{2}{|c|}{$\begin{array}{c}\text { Conc. in solution } \\
\text { [mol\%] }\end{array}$} & \multicolumn{2}{|c|}{$\begin{array}{c}\text { Conc. in crystal } \\
{[\mathrm{mol} \%]}\end{array}$} & \multicolumn{2}{|c|}{$\begin{array}{c}\text { OH- band } \\
{\left[\mathrm{cm}^{-1}\right]}\end{array}$} \\
\hline & $\mathrm{Fe}$ & Ti & $\mathrm{Fe}$ & Ti & $\mathrm{Fe}$ & Ti \\
\hline \multirow[t]{3}{*}{1} & 0.06 & 0 & - & - & - . & - \\
\hline & 0.12 & 0 & 0.056 & - & - & - \\
\hline & 0.5 & 0 & 0.23 & - & 3502 & - \\
\hline \multirow[t]{3}{*}{2} & 0 & 0.012 & - & - & - & - \\
\hline & 0 & 0.06 & - & - & - & - \\
\hline & 0 & 0.12 & - & 0.077 & - & 3485 \\
\hline \multirow[t]{4}{*}{3} & 0.012 & 0.012 & - & - & - & - \\
\hline & 0.06 & 0.06 & - & - & - & $3485 w$ \\
\hline & 0.12 & 0.12 & 0.068 & 0.069 & $3502 v w$ & 3485 \\
\hline & 0.24 & 0.12 & 0.13 & 0.048 & $3502 w$ & 3485 \\
\hline
\end{tabular}

L. Kovács, L. Kocsor, É. Tichy-Rács, K. Lengyel, L. Bencs, and G. Corradi: Hydroxyl ion probing transition metal dopants occupying $\mathrm{Nb}$ sites in stoichiometric $\mathrm{LiNbO}_{3}$, Optical Materials Express, 9, 4506-4516, 2019. 


\section{i) $\mathrm{OH}^{-}$ions in $\mathrm{Fe}^{3+}$ - and $\mathrm{Ti}^{4+}$-doped SLN}
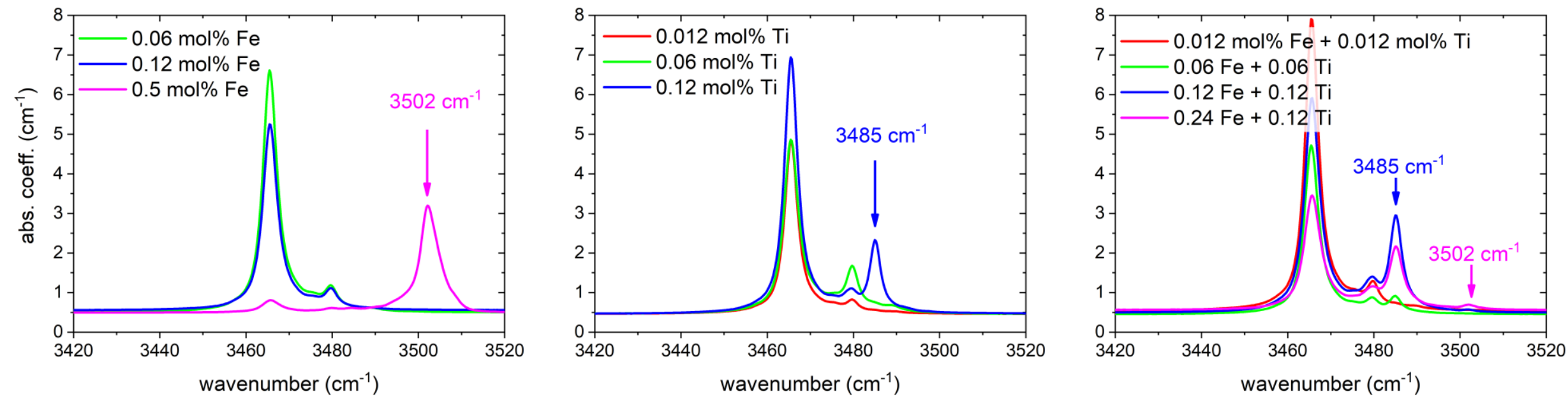

- Above a threshold concentration of the $\mathrm{TM}^{\mathrm{n}+}$ dopants new $\mathrm{OH}^{-}$absorption bands appear in SLN crystals 


\section{i) Hydroxyl ions in $\mathrm{Cr}^{3+}$-doped SLN}
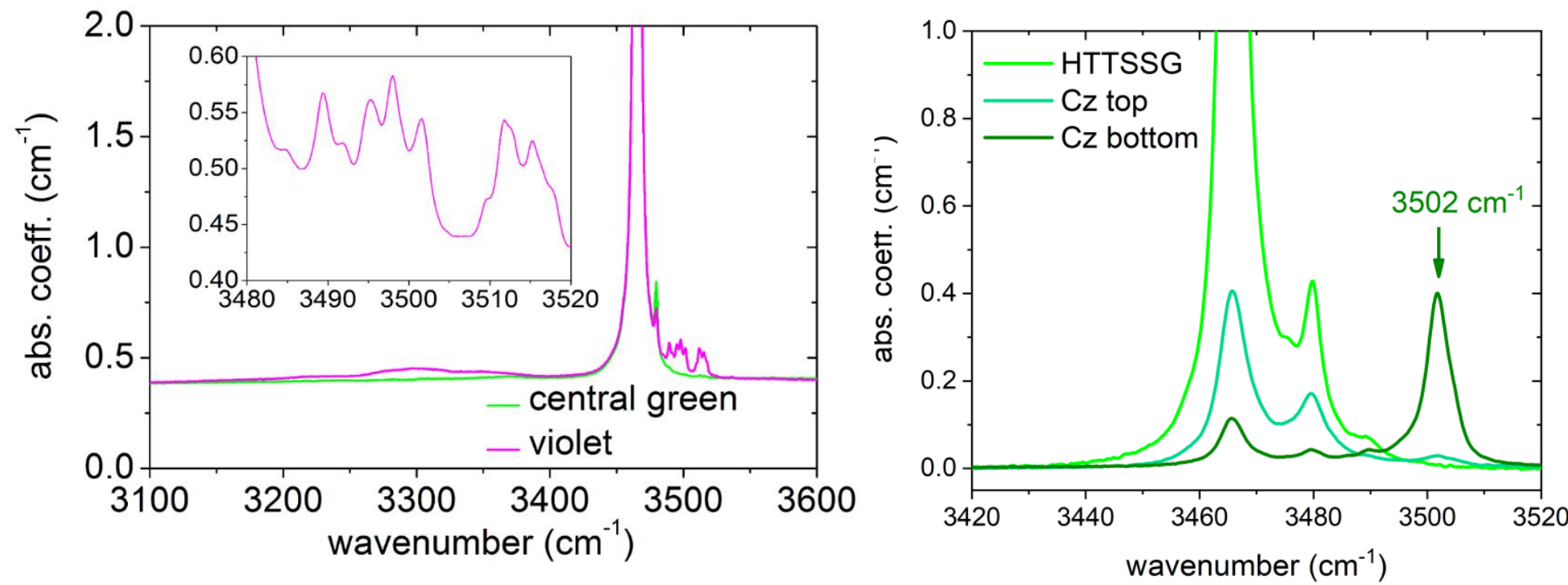

- In the inhomogeneous bottom part of Cr-doped SLN a number of narrow overlapping $\mathrm{OH}^{-}$bands appeared due to $\mathrm{Cr}-\mathrm{OH}$ centres with different defect environments

- Due to the composition change (becoming more stoichiometric) a single $\mathrm{OH}^{-}$band appears at $3502 \mathrm{~cm}^{-1}$ at the bottom part of the Czochralski-grown crystal similarly to the Fe-doped SLN

Crystals 2020 


\section{i) $\mathrm{TM}^{\mathrm{n}+}$ ions in stoichiometric $\mathrm{LiNbO}_{3}$}
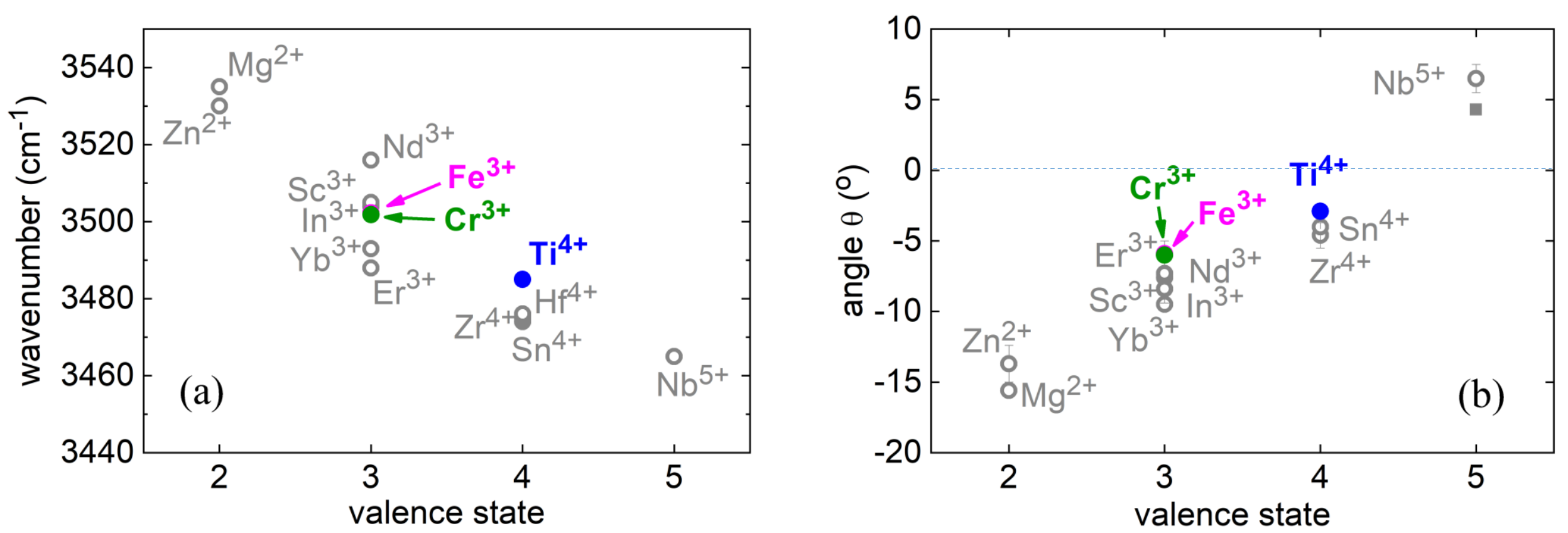

- The higher the valence state of the dopant, the lower the $\mathrm{OH}^{-}$vibrational frequency and the closer the $\mathrm{O}-\mathrm{H}$ bond direction to the oxygen plane

- The observed trend is valid for all dopants studied so far 


\section{ii) Mechanochemical reactions of $\mathrm{LiNbO}_{3}$ induced by high-energy ball-milling}

- Lithium niobate nanocrystals

- High-energy ball-milling (dry and wet grinding)

- Particle and grain size reduction

- Phase transformation and chemical reaction

- Structure characterization (X-ray, Raman, reflection spectroscopy, coulometric titration, electron microscopy)

Crystals 2020 


\section{ii) $\mathrm{LiNbO}_{3}$ nanocrystals}

- Can be used e.g. in

- Nonlinear optics - as harmonic nanoparticles (HNP) in nanobiophotonics

- Quantum optics - rare-earth doped LN as single photon source

- Can be prepared by

- „Bottom up” method

- Mechanochemical calcination (grinding + heat treatment)

- Wet chemical, sol-gel, hydrothermal, combustion, etc.

- „Top down” method

- High-energy ball-milling (dry and wet grinding) for particle and grain size reduction

- Shaker mill - Spex mixer mill

- Planetary mill - Fritsch Pulverisette

- Etching

\section{Crystals} 2020 


\section{ii) High-energy ball-milling}

Dry grinding in SPEX shaker mill

\begin{tabular}{|c|c|c|c|c|c|c|c|}
\hline \multicolumn{8}{|c|}{ Grinding parameters } \\
\hline$\#$ & Vial & Ball & Time (h) & $\begin{array}{c}\text { Number of } \\
\text { balls }\end{array}$ & $\begin{array}{l}\text { Ball-to- } \\
\text { powder } \\
\text { mass ratio }\end{array}$ & $\begin{array}{c}\text { Ball-to- } \\
\text { powder } \\
\text { volume ratio }\end{array}$ & $\begin{array}{l}\text { Sample } \\
\text { quantity } \\
\text { (g) }\end{array}$ \\
\hline SS-5 & $\begin{array}{c}\text { Stainless } \\
\text { steel }\end{array}$ & $\begin{array}{c}11 \mathrm{~mm} \\
5.5 \mathrm{~g}\end{array}$ & 5 & 2 & $3.8: 1$ & $2.2: 1$ & 2.9 \\
\hline ALO-5 & \multirow{2}{*}{ Alumina } & \multirow{2}{*}{$\begin{array}{l}12.5 \\
\mathrm{~mm} \\
4.2 \mathrm{~g}\end{array}$} & 5 & \multirow{2}{*}{2} & \multirow{2}{*}{$3.8: 1$} & \multirow{2}{*}{$4.4: 1$} & \multirow{2}{*}{2.2} \\
\hline ALO-20 & & & 20 & & & & \\
\hline TC-5 & $\begin{array}{l}\text { Tungsten } \\
\text { carbide }\end{array}$ & $\begin{array}{l}11 \mathrm{~mm} \\
10.7 \mathrm{~g}\end{array}$ & 5 & 2 & $3.8: 1$ & $1.2: 1$ & 5.65 \\
\hline
\end{tabular}

L. Kocsor, L. Péter, G. Corradi, Z. Kis, J. Gubicza and L. Kovács: Mechanochemical reactions of lithium niobate induced by high energy ball-milling, Crystals, 9, 334/1-14, 2019.

Crystals 


\section{ii) High-energy ball-milling}

Dry grinding in SPEX shaker mill

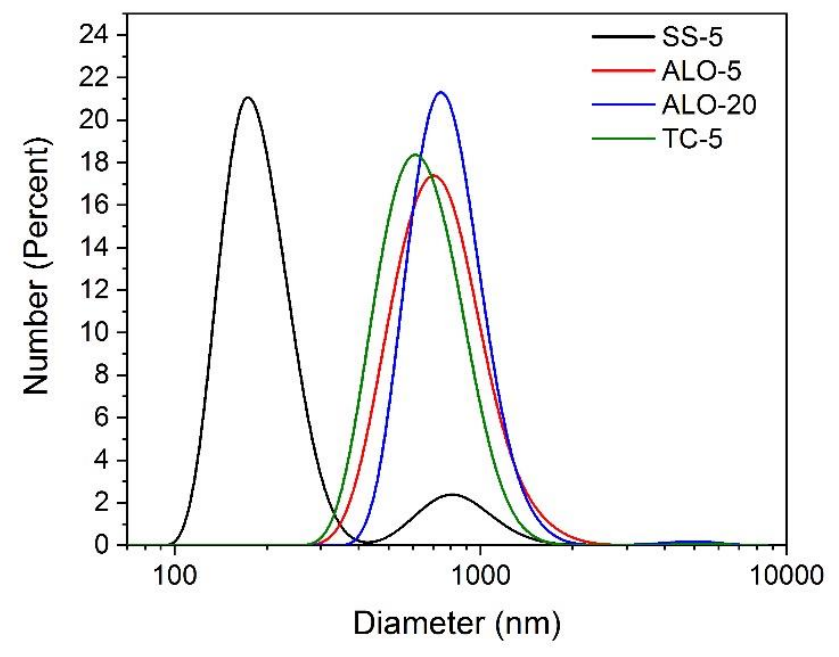

Particle diameter distributions of the ground samples in different vials determined by the Dynamic Light Scattering (DLS) method

\begin{tabular}{c|c|c}
$\#$ & $\begin{array}{c}\text { Resulting particle } \\
\text { diameter }(\mathbf{n m}) \\
\text { DLS }\end{array}$ & $\begin{array}{c}\text { Resulting grain } \\
\text { diameter }(\mathbf{n m}) \\
\text { XRD }\end{array}$ \\
\hline SS-5 & $190,(800)$ & $55 \pm 18$ \\
\hline ALO-5 & 700 & $63 \pm 21$ \\
\hline ALO-20 & 700 & $37 \pm 2$ \\
\hline TC-5 & 500 & $51 \pm 6$
\end{tabular}

Particle and grain sizes of samples ground in different vials 


\section{ii) High-energy ball-milling}

Dry grinding in SPEX shaker mill

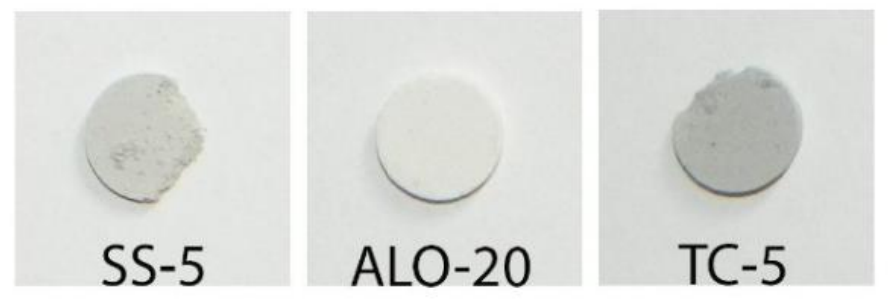

Sample coloration

- Al was detected in the sample ground in alumina vial

- No Fe and $\mathbf{W}$ were detected in samples ground in stainless steel and tungsten carbide vials, respectively

- The coloration is not related to contamination

Energy-dispersive X-ray spectroscopy
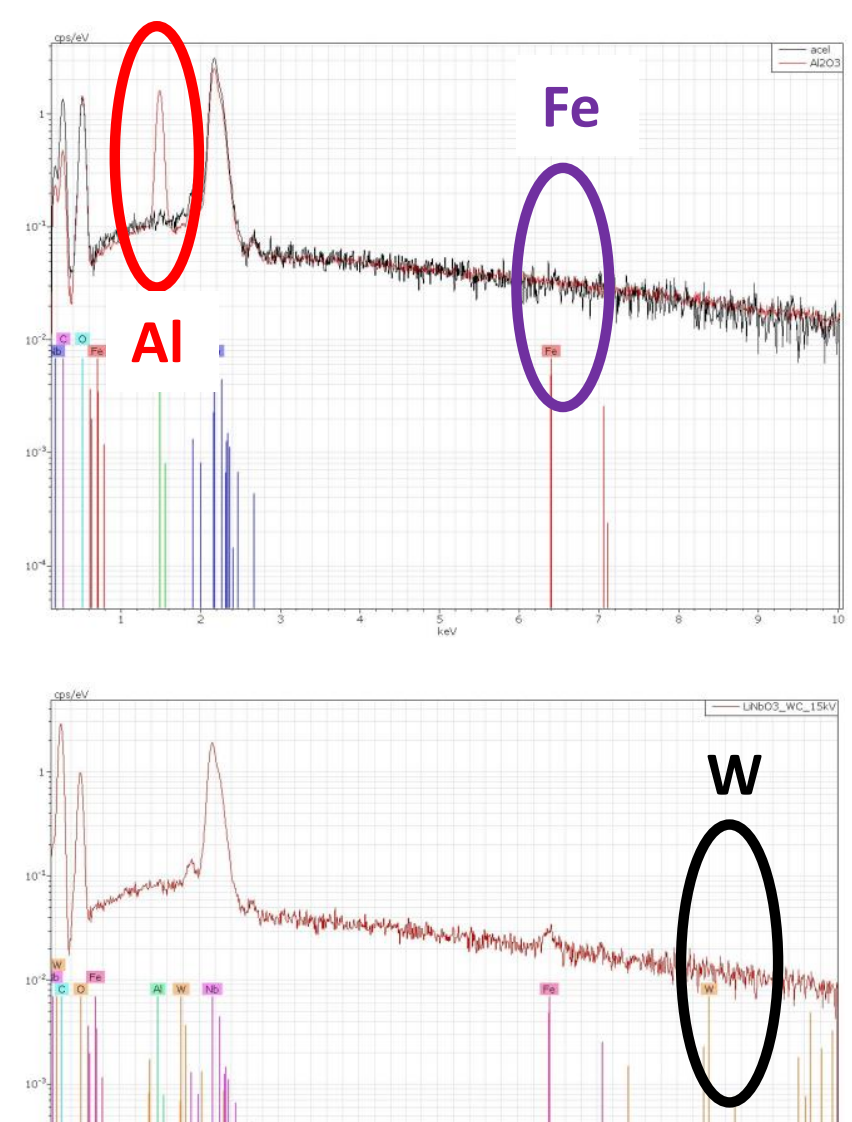

Crystals 2020 


\section{ii) High-energy ball-milling}

Dry grinding in SPEX shaker mill

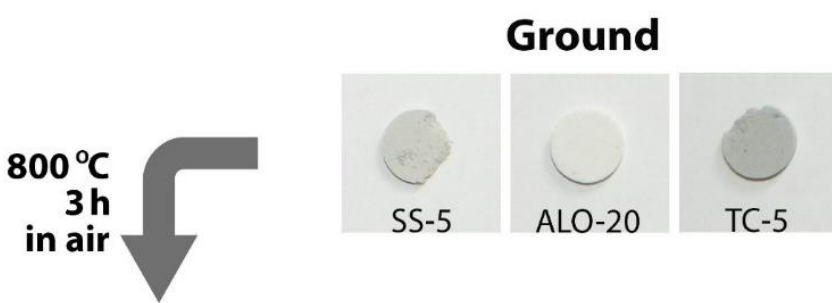

Oxidized
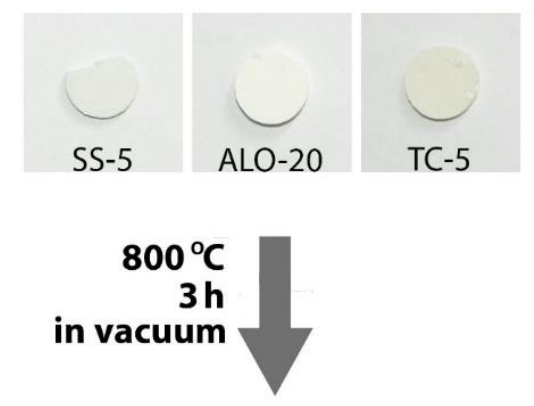

Oxidized-reduced

\begin{tabular}{l|l|l} 
SS-5 & ALO-20 & TC-5
\end{tabular}

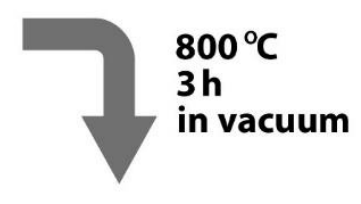

Reduced
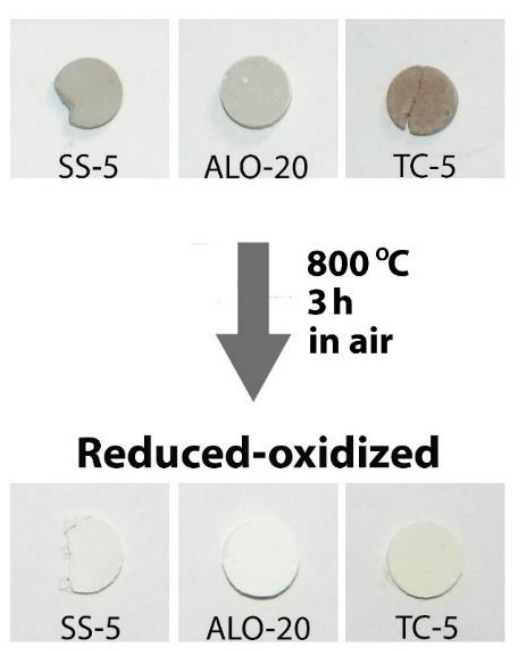

The samples underwent a change concerning the oxidation state of niobium during the grinding process.

Annealing treatments in oxidative or non-oxidative atmospheres was applied for restoring or modifying the oxidation state of niobium in the ground samples.

The series of samples ground in different vials with subsequent heat treatments 


\section{ii) High-energy ball-milling}

Dry grinding in SPEX shaker mill

\section{X-ray diffraction}
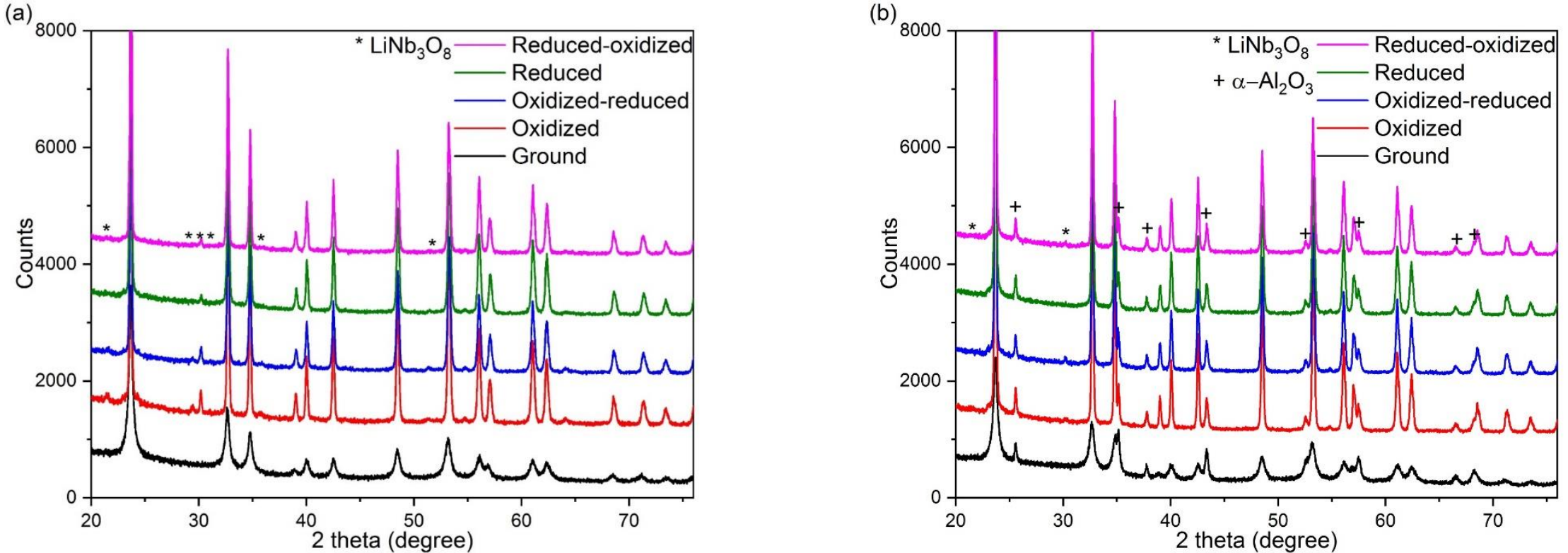

Diffraction patterns of LN ground in stainless steel (a) and alumina (b) vials The unmarked peaks are the reflections of $\mathrm{LiNbO}_{3}$

- As-ground samples - broad peaks - small grain size

- Heat-treatment results in narrower diffraction lines due to increased grain sizes

- $\mathrm{LiNb}_{3} \mathrm{O}_{8}$ phase appeared in annealed samples

$$
3 \mathrm{LiNbO}_{3}=\mathrm{LiNb}_{3} \mathrm{O}_{8}+\mathrm{Li}_{2} \mathrm{O}
$$

L. Kocsor, L. Péter, G. Corradi, Z. Kis, J. Gubicza and L. Kovács: Mechanochemical reactions of lithium niobate induced by high energy ball-milling, Crystals, 9, 334/1-14, 2019. 


\section{ii) High-energy ball-milling}

Dry grinding in SPEX shaker mill

(a)

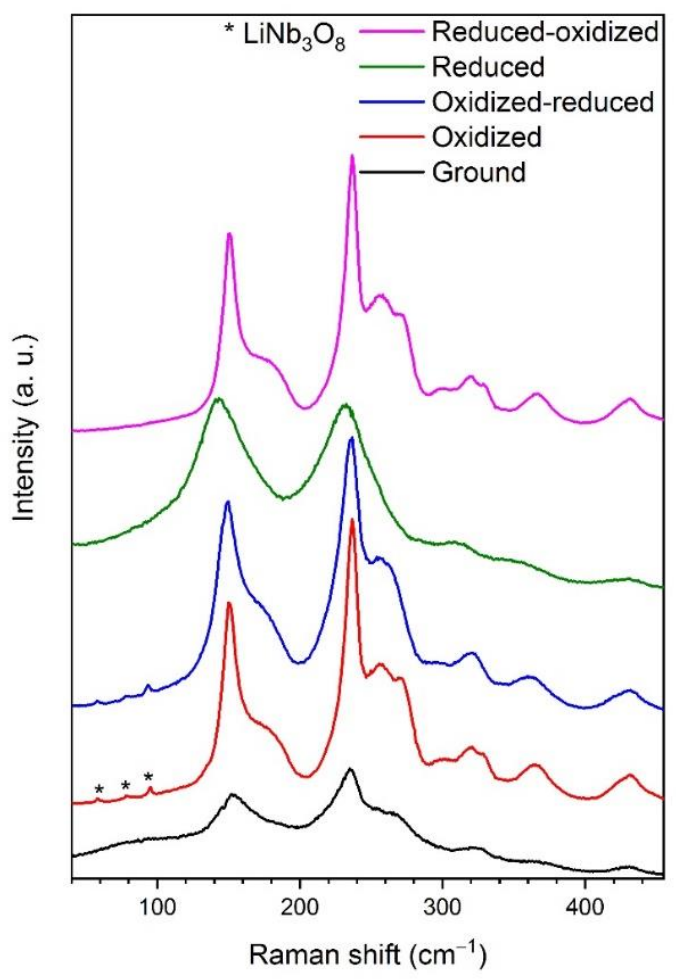

Raman spectroscopy

(b)

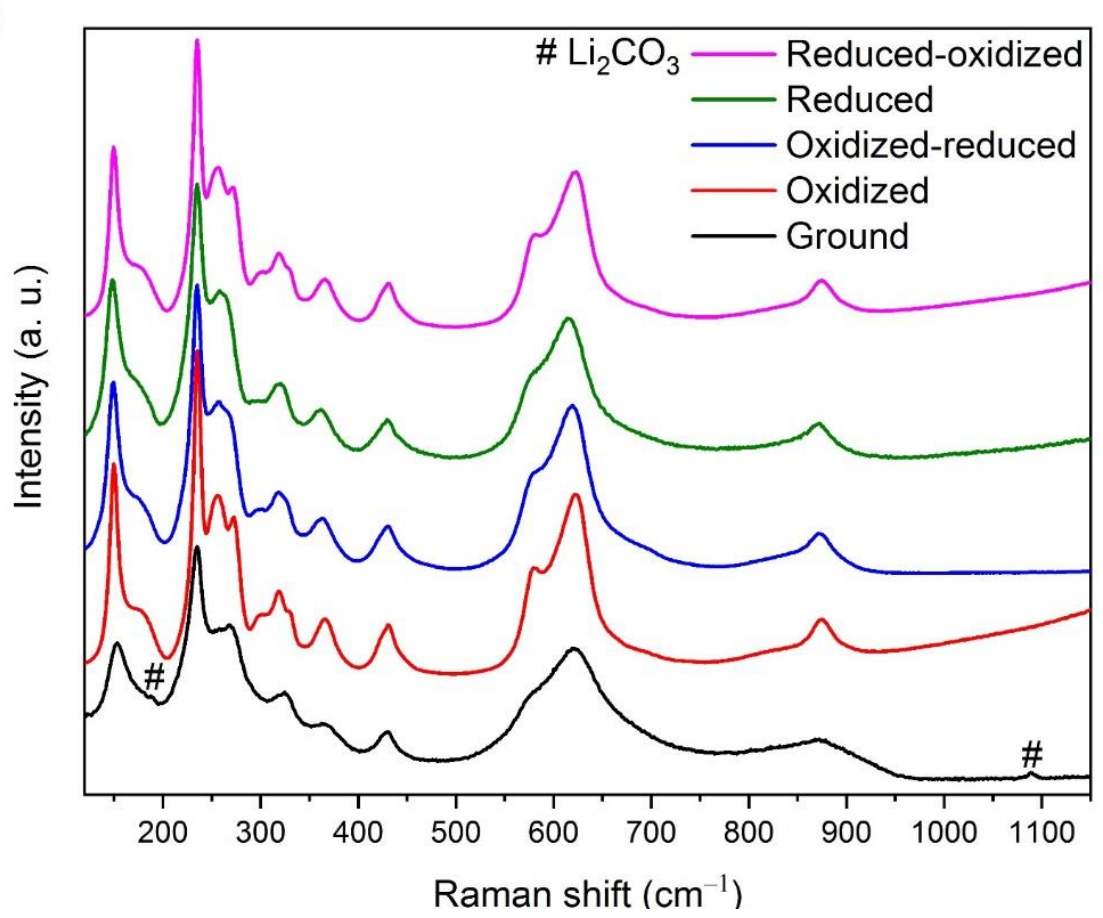

Raman spectra of ground and heat-treated samples ball-milled for $5 \mathrm{~h}$ in stainless steel (a), and in tungsten carbide vial (b)

L. Kocsor, L. Péter, G. Corradi, Z. Kis, J. Gubicza and L. Kovács: Mechanochemical reactions of lithium niobate induced by high energy ball-milling, Crystals, 9, 334/1-14, 2019. 


\section{ii) High-energy ball-milling}

Dry grinding in SPEX shaker mill

\section{Optical reflection measurements}
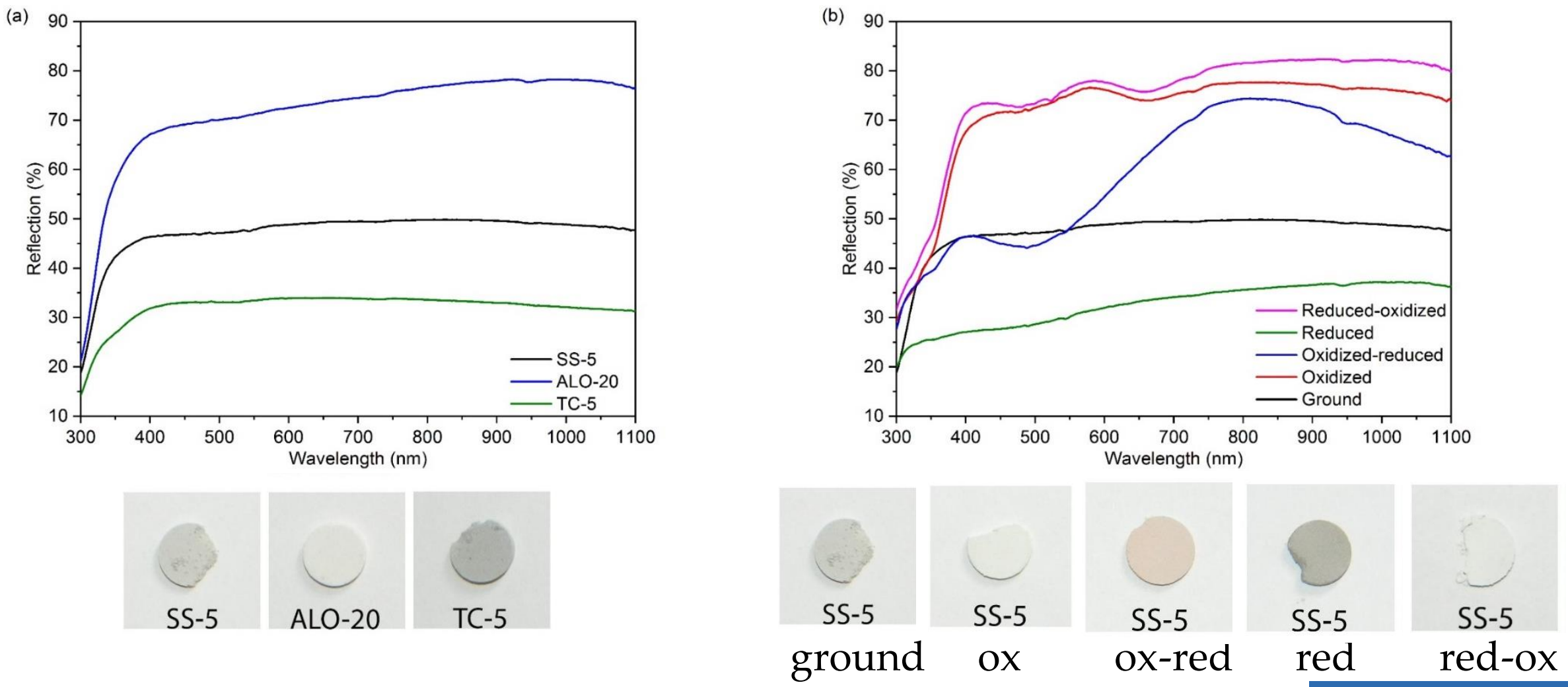

Optical reflection spectra of samples ball-milled in different vials (a) and of ground and heat-treated samples ball-milled in stainless steel vial (b)

L. Kocsor, L. Péter, G. Corradi, Z. Kis, J. Gubicza and L. Kovács: Mechanochemical reactions of lithium niobate induced by high energy ball-milling, Crystals, 9, 334/1-14, 2019.

Crystals 2020 


\section{ii) High-energy ball-milling}

Dry grinding in SPEX shaker mill

- Congruent $\mathrm{LiNbO}_{3}$ crystals:

- $\mathrm{Li}_{1-5 \mathrm{x}} \mathrm{Nb}_{1+\mathrm{x}} \mathrm{O}_{3}, \mathrm{x} \approx 0.01$

- $\mathrm{Nb}_{\mathrm{Li}}{ }^{4+}$ : small polaron

- $\mathrm{Nb}_{\mathrm{Li}}{ }^{4+}-\mathrm{Nb}_{\mathrm{Nb}}^{4+}$ : bipolaron

- Ball-milling

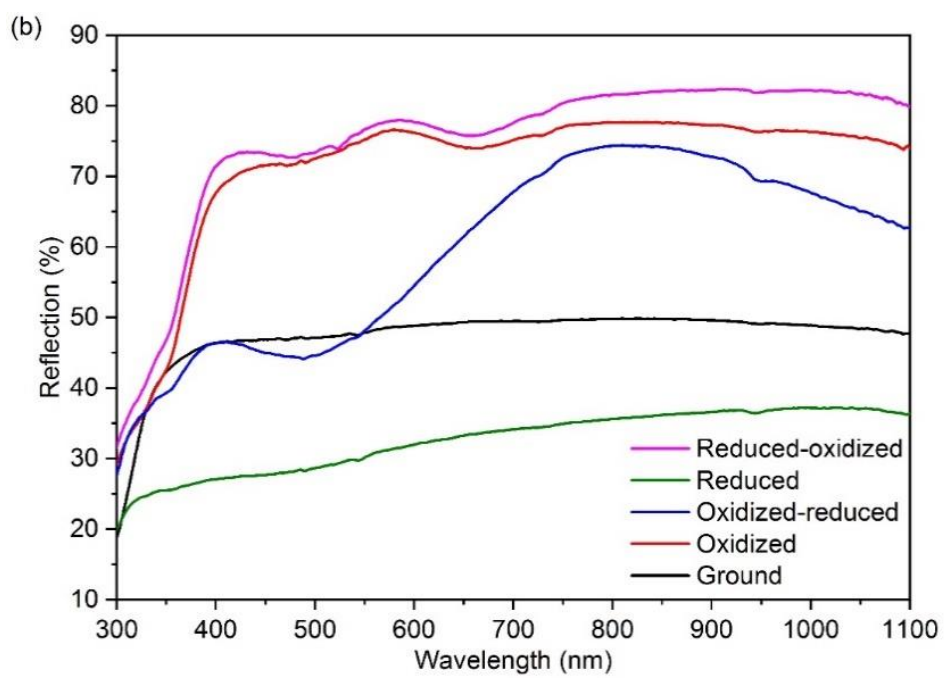

$$
2 \mathrm{LiNbO}_{3} \rightarrow \mathrm{Nb}_{\mathrm{Nb}}^{4+}+\mathrm{Nb}_{\mathrm{Li}}^{4+}+3 \mathrm{O}_{\mathrm{O}^{2-}}+2 \mathrm{e}^{-}+\mathrm{Li}_{2} \mathrm{O} \uparrow+\mathrm{O}_{2} \uparrow
$$

- Oxidation

$$
\mathrm{LiNbO}_{3}+\mathrm{Nb}_{\mathrm{Nb}}{ }^{4+}+\mathrm{Nb}_{\mathrm{Li}}{ }^{4+}+3 \mathrm{O}_{\mathrm{O}}^{2-}+2 \mathrm{e}^{-}+\mathrm{O}_{2} \rightarrow \mathrm{LiNb}_{3} \mathrm{O}_{8}
$$




\section{ii) High-energy ball-milling}

Dry grinding in SPEX shaker mill

Quantitative determination of the degree of

decomposition during ball-milling

- Coulometric titration $m_{\mathrm{OX}}=M Q / 2 F$

M: molar weight of $\mathrm{Li}_{2} \mathrm{O}$

Q: charge passed until the equivalence point

F: Faraday-constant $(96485 \mathrm{C} / \mathrm{mol})$

2: the hydrolysis of $1 \mathrm{~mol}$ of $\mathrm{Li}_{2} \mathrm{O}$ results in 2 mols of hydroxide ions

\begin{tabular}{c|c|c} 
Sample & $\begin{array}{c}100 \mathrm{w}_{\text {ox }} \\
\text { (weight\%) }\end{array}$ & $\begin{array}{c}\text { Mean particle radius, DLS } \\
\text { (nm) }\end{array}$ \\
\hline ALO-20 & $0.97 \pm 0.05$ & 350 \\
\hline TC-5 & $1.05 \pm 0.10$ & 250 \\
\hline SS-5 & $1.52 \pm 0.21$ & 95
\end{tabular}

The measured $\mathrm{Li}_{2} \mathrm{O}$

mass ratios $w_{\mathrm{ox}}$ expressed as weight percent of the asground powder

L. Kocsor, L. Péter, G. Corradi, Z. Kis, J. Gubicza and L. Kovács: Mechanochemical reactions of lithium niobate induced by high energy ball-milling, Crystals, 9, 334/1-14, 2019.

Crystals 


\section{ii) High-energy ball-milling}

Dry grinding in SPEX shaker mill

Estimation of the thickness of the $\mathrm{LiNb}_{3} \mathrm{O}_{8}$ layer

- Assumptions

- Uniform spherical LN particles of unmodified composition

- Uniformly thick $\mathrm{LiNb}_{3} \mathrm{O}_{8}$ layer

- $d<<R$

$w_{\mathrm{OX}}=\frac{m_{\mathrm{LTN}} \frac{M_{\mathrm{OX}}}{M_{\mathrm{LTN}}}}{m_{\mathrm{LN}}+m_{\mathrm{LTN}}\left(1+\frac{M_{\mathrm{OX}}}{M_{\mathrm{LTN}}}\right)}$, weight ratio of $\mathrm{Li}_{2} \mathrm{O}$ in the ground material

$d_{\mathrm{LTN}} \approx \frac{R}{3} \frac{\rho_{\mathrm{LN}}}{\rho_{\mathrm{LTN}}} \frac{M_{\mathrm{LTN}}}{M_{\mathrm{OX}}} w_{\mathrm{OX}}$ and $d_{\mathrm{OX}} \approx \frac{\rho_{\mathrm{LTN}}}{\rho_{\mathrm{OX}}} \frac{M_{\mathrm{OX}}}{M_{\mathrm{LTN}}} d_{\mathrm{LTN}} \approx \frac{d_{\mathrm{LTN}}}{5.6}$

\begin{tabular}{c|c|c|c|c|c} 
Sample & $\begin{array}{c}\mathbf{1 0 0}_{\text {ox }} \\
\text { (weight\%) }\end{array}$ & $\begin{array}{c}\text { Mean particle } \\
\text { radius, DLS } \\
(\mathbf{n m})\end{array}$ & $\begin{array}{c}\text { Mean grain } \\
\text { radius, XRD } \\
(\mathbf{n m})\end{array}$ & $\begin{array}{c}\text { dLTN LiNb3O8 } \\
\text { shell thickness } \\
\text { (nm) }\end{array}$ & $\begin{array}{c}\text { dox Li2O } \\
\text { shell thickness } \\
\text { (nm) }\end{array}$ \\
\hline ALO-20 & $0.97 \pm 0.05$ & 350 & 18.5 & 14.6 & 2.6 \\
\hline TC-5 & $1.05 \pm 0.10$ & 250 & 25.5 & 11.3 & 2.0 \\
\hline SS-5 & $1.52 \pm 0.21$ & 95 & 27.5 & 6.2 & 1.1
\end{tabular}

L. Kocsor, L. Péter, G. Corradi, Z. Kis, J. Gubicza and L. Kovács: Mechanochemical reactions of lithium niobate induced by high energy ball-milling, Crystals, 9, 334/1-14, 2019. 


\section{ii) High-energy ball-milling}

Dry and wet grinding in Fritsch planetary mill

\section{Recent results}

\begin{tabular}{c|c|c|c|c|c|c}
\multicolumn{7}{c}{ Grinding parameters } \\
\hline & Vial / Ball & RPM & Time & Solvent & $\begin{array}{c}\text { Ball size / } \\
\text { quantity }\end{array}$ & $\begin{array}{c}\text { Sample } \\
\text { quantity }\end{array}$ \\
DRY & $\mathrm{ZrO}_{2}$ & 1100 & $10 \times 1 \mathrm{~min}$ & - & $0.5-3 \mathrm{~mm} / 70 \mathrm{~g}$ & $5 \mathrm{~g}$ \\
\hline WET & $\mathrm{ZrO}_{2}$ & 1100 & $10 \times 1 \mathrm{~min}$ & $10 \mathrm{ml}$ water & $0.1-3 \mathrm{~mm} / 70 \mathrm{~g}$ & $5 \mathrm{~g}$ \\
\hline
\end{tabular}

Crystals 


\section{ii) High-energy ball-milling}

Dry and wet grinding in Fritsch planetary mill

\section{Recent results}
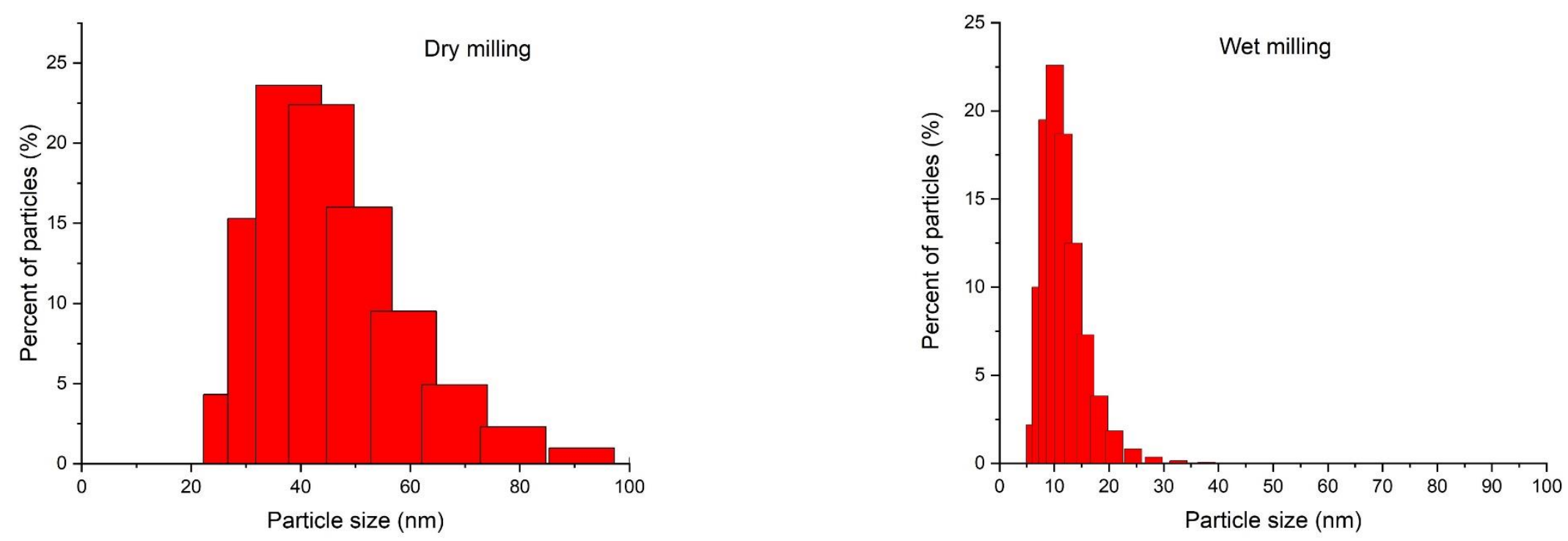

Size distribution measured by Dynamic Light Scattering (DLS)

\section{Crystals} 2020 


\section{ii) High-energy ball-milling}

Dry grinding in Fritsch planetary mill

\section{Recent results}
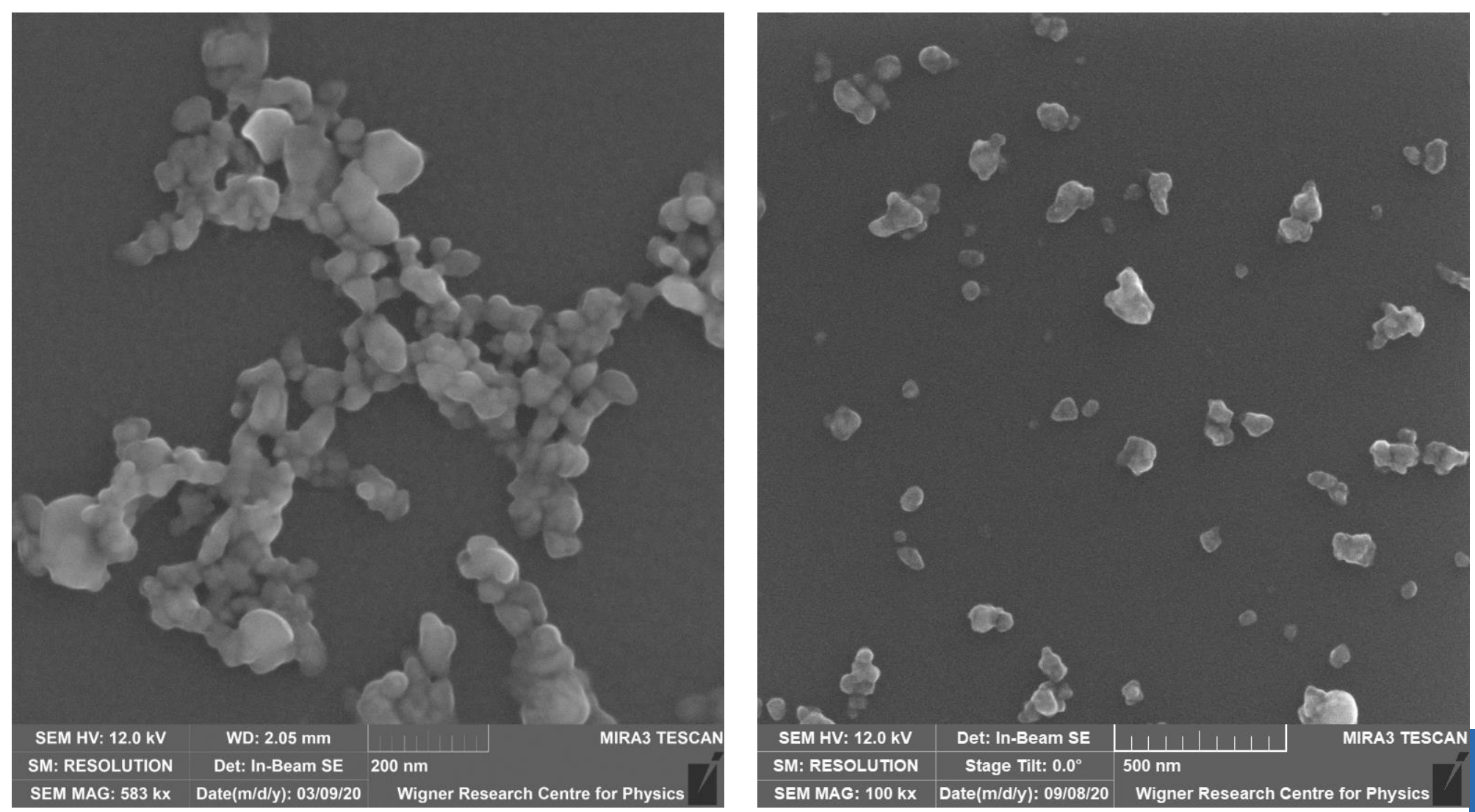

Scanning electron microscopy (SEM) images of the $\mathrm{LiNbO}_{3}$ particles 


\section{ii) High-energy ball-milling}

Wet grinding in Fritsch planetary mill

\section{Recent results}

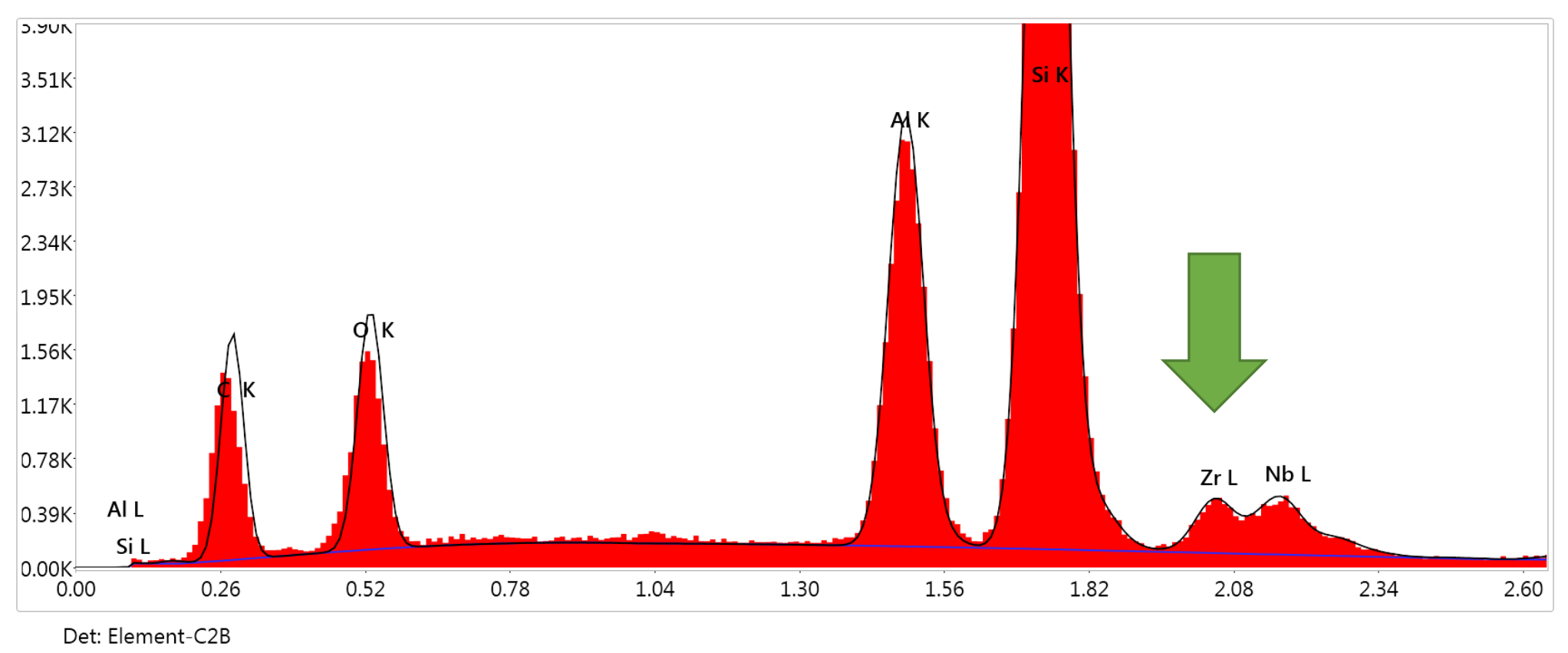

The material (Zr) of the vial/ball is present in the particles measured by EDAX

Crystals 2020 


\section{ii) High-energy ball-milling}

Dry grinding in Fritsch planetary mill

\section{Recent results}

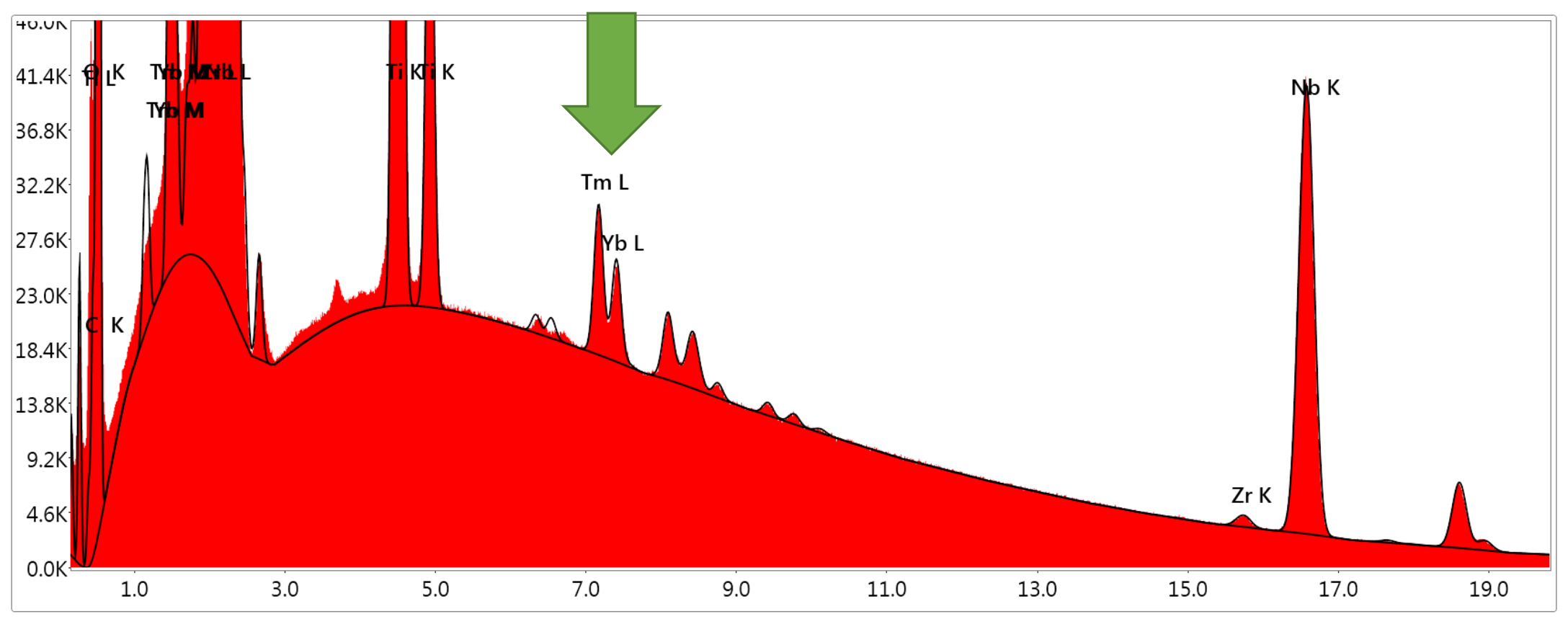

Dopants (Tm and $\mathrm{Yb}$ ) planned to use in single photon source are present in the particles 


\section{ii) High-energy ball-milling - Summary}

- Nano-LN (10-50 nm particle size) has been successfully prepared by high-energy ball-milling

- During the milling process the material suffers partial reduction interpreted by polaron/bipolaron formation.

- $\mathrm{Li}_{2} \mathrm{O}$ loss and $\mathrm{LiNb}_{3} \mathrm{O}_{8}$ formation was observed in the outer shell of the particles

- These findings provide a comprehensive explanation of the physicochemical behaviour of the system during grinding and annealings.

- $\mathrm{RE}^{3+}$-doped nano-LN has been successfully prepared for single photon source 


\section{Conclusions}

- $\mathrm{LiNbO}_{3}$ either in single crystal or in nanocrystalline form is one of the most versatile materials for optical applications

- The study of both intrinsic and extrinsic defects affecting the properties of LN may provide new results for future applications 


\section{Acknowledgment}

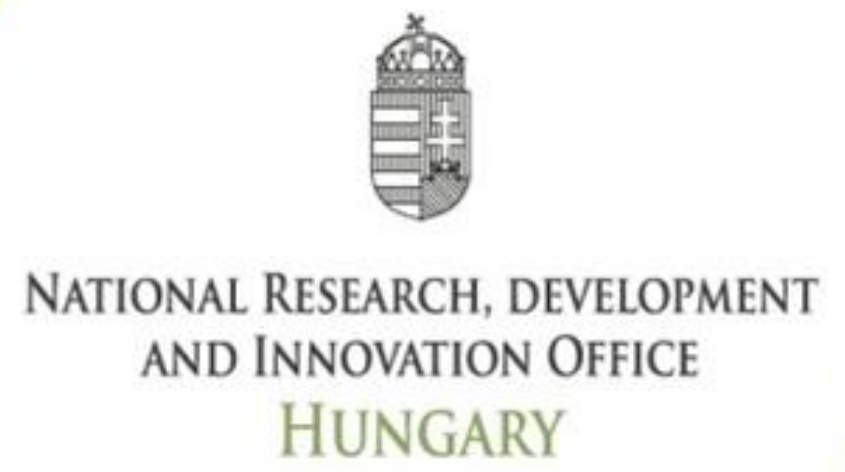

\section{PROJECT FINANCED FROM THE NRDI FUND \\ MOMENTUM OF INNOVATION}

Crystals 2020 